\title{
ÇERKES ETHEM HADISESININ NUTUK TEMELLI İNCELENMESI
}

\section{Sezai Kürşat ÖKTE*}

$\ddot{O} z$

Çerkes Ethem, Milli Mücadele’nin başlangıç safhasında gerek cephede Yunan birliklerine karşı, gerekse yurt içinde meydana gelen ayaklanmalarda, kendisine bağlı Kuvayı Seyyare birlikleriyle etkili olarak faaliyet göstermiştir. Ancak zaman içerisinde, çevresinin de etkisinde kalarak, başta Mustafa Kemal Paşa olmak üzere Milli Mücadele liderlerini kendisiyle eş değer tutmaya başlamıştır. Yeşil Ordu Cemiyetine mensubiyetini ve Yeni Dünya Gazetesi ile să̆ladı̆̆ imkânları kendi çıkarları için kullanmıştır. Özellikle Kuvayı Milliye'den düzenli orduya geçiş sürecinde kendisi ve kardeşleri, kurulmaya çalışılan emir ve komuta sistemini kabullenmemişlerdir. Adeta bir isyan niteliği taşıyan davranışları öncelikle nasihatle yola getirilmeye çalışılmış, ancak bundan bir sonuç alınamayınca, cephelerinde bulunan Yunan kuvvetleriyle birlikte sürülmüşlerdir. Böylece Çerkes Ethem ve kardeşleri, Milli Mücadele tarihinin çok talihsiz bir konumuna mahkûm edilmişlerdir. Gazetesi.

Anahtar Kelimeler; Çerkes Ethem, Kuvayı Seyyare, Yeşil Ordu, Yeni Dünya

\section{A Review of Çerkes Ethem Event from the Nutuk's Perspective}

\section{Abstract}

At the initial stage of the National Struggle, Çerkes Ethem together with Kuvayl Seyyare units belonged to him, acted effectively through taking sides against either the Greek forces or rebellions in the country. However, under the influence of his environment he began to put himself on equal foot with first Mustafa Kemal Pasha and other leaders of the National Struggle over time. He used his membership of the Green Army Society and facilities provided by the New World Newspaper for his own interests. In particular, he and his brothers were not willing to accept the establishment of order and command system during the transition process from Kuva-yı Milliye to the regular army. Their almost open rebellionwise behaviors

* Ankara Üniversitesi, Türk İnkılap Tarihi Enstitüsü 
were first tolerated through advice but due to the inconsequency of this attempt, they were exiled together with Greek forces on their sides. As a result, Çerkes Ethem and his brothers were sentenced to an unfortunate position of the history of National Struggle.

Keywords: Çerkes Ethem, Kuva-yl Seyyare, Yeşil Ordu (Green Army), Yeni Dünya Gazetesi (New World Newspaper).

\section{Nutuk'ta Çerkes Ethem ile İlgili Açıklanan Hususlar: \\ Çerkes Ethem Yeşil Ordu İlişkisisi:}

Nutuk'ta, Çerkes Ethem hadisesi ilk olarak, Yeşil Ordu ${ }^{1}$ hakkında yapılan açıklamalarda yer almaktadır. Yeşil Ordu teşkilatının kurucuları arasında, mebus olan Çerkes Reşit Bey'in bulunduğu, Ankara üzerinden Yozgat'a gidip gelirken Çerkes Ethem ve kardeşi Tevfik Beyin de Yeşil Ordu'ya katıldığı, Çerkes Ethem ve Tevfik Bey müfrezelerinin, Yeşil Ordunun adeta esasını teşkil ettikleri belirtilmektedir. ${ }^{2}$

\footnotetext{
${ }^{1}$ Ali Fuat Cebesoy, Milli Mücadele Hatıraları, Temel Yayınları, İstanbul, 2010, s. 527-529. Yeşil Ordu Cemiyeti Umumi Katibi, Hakkı Behiç Bey tarafından Yeşil Ordu'nun gerçek durumu şu şekilde açıklanmaktadır: "Sivas Kongresini müteakip, Batı'nın memleketimizi yok etmek isteyen siyaseti karşısında Şarka ve Rus Inkılabına yaklaşmanın memleketimiz için bir ümit ışığı olduğunu görmüştüm. Müslüman aleminde Rus Inkılabını tadilen vücuda getirilecek bir sosyalist ittihadı fikrine bağlıydım. Bu fikrimi Mustafa Kemal Paşa'ya da açmıştım. Paşa taraftar görünmüş̧ü. Memleket dahilinde Rus Bolşevizmine muvazi bir cereyan hazırlamaya başlamış ve haricen kamuoyunu hazırlamak üzere gizli bir teşkilat vücuda getirmiştik. Gizli olarak vücuda getirdiğimiz teşkilatın adı Yeşil Orduydu. Aynı zamanda Türkistan'da, Iran'da, Azerbaycan'da diğer bir çok teşekküllerin bulunduğunu haber almıștık. Oralarda faaliyetlerde bulunan arkadaşlarımızla muhabere ederek, onların da mesaisinden faydalanmak ve hudutlarımı dışındaki teşkilatı memleket dahiline bağlamak istedik. Bu suretle bir taraftan yeni kabul edecekleri sosyalist siyaseti ile korumayl, diğer taraftan bizi bütün bu İslam kitleleri ile birlikte hareket eder gibi göstererek kuvvetlendirmeyi düşündük. Ĕger biz bu siyasetimizde muvaffak olursak, Ruslar, Ruslar Müslüman memleketleriyle ayr ayrt siyaset yapacaklart yerde bizimle siyaset yapmak, veyahut bizi tutmakla bütün İslam alemini tutacaklarina kani olacaklardı. Bu hareketimizle diğer mühim bir nokta-i nazarı da halledecektik. Hariçte çalışan arkadaşlarımız, bu memleketin bizim kadar hak sahibi evlatlarıydı. Düşmanlarımızın takip ve baskılarından firara mecbur olmuş kimselerdi. Memlekete dönemedikleri bir zamanda kendilerine az veya çok yardım imkanı vermiş olacak ve onları daha büyük bir gayretle bulundukları muhitlerde çalıştıracaktık. T.B.M.M. açıldıktan sonra meydana cemiyet olarak çıkmış ben de umumi katipleri olmuştum. Cemiyetin teşkilatı bir hayli büyüdükten ve genişledikten sonra Mustafa Kemal Paşa'nın emniyetini kaybetmişti. Bunun üzerine cemiyeti dağıtmak mecburiyetinde kaldık. Bizi dinlemeyerek faaliyette devam ve sebat edenler birer vesileyle mahkum oldular."

${ }^{2}$ Gazi Mustafa Kemal, Nutuk, Ankara, 1927, s. 345-346.
} 


\section{Yozgat İsyanı Öncesi ve Sonrası Gelişmeler:}

Çerkes Ethem'in, milli bir müfreze ile önce Anzavur ve daha sonra Düzce isyanında başarılı hizmetler görmesi nedeniyle, Yozgat'a gönderilmek üzere Ankara'ya çağrıldığı zaman; Ankara'da herkes tarafından takdir edildiği, bazılarının bunu biraz abarttığı, Ethem ve kardeşlerinin gösterilen bu ilgiden çok etkilenerek gururlandıkları ve bazı olmayacak hayallere kapıldıkları; Yozgat isyanını bastırma esnasında, kendilerine uzak ve yakın ne kadar askeri ve milli kumandanlar varsa, bunların rütbe ve makamlarını dikkate almaksızın hepsine karşı gelmekte sakınca görmedikleri; Türk Ordusu'nda kendilerinden başka subay ve kumandan olmayıp, kendilerinin birer kahraman olduğu hissine kapıldıkları; söz konusu kumandanların ise, ülkenin içinde bulunduğu durumu dikkate alarak ve bunların faaliyetlerini göz önünde bulundurarak, kendileriyle ilişkiye girmekten çekindikleri; bu davranışlardan iyice cesaret alan Ethem ve Tevfik kardeşlerin, bölgedeki valilere dahi emirler vermeye, onları tehdit etmeye başladıkları, Milli Mücadele esnasında çok yararlılıkları bulunan Ankara Valisi Yahya Galip Bey'in idamına dahi karar verdikleri; Yozgat'ta bulunan mebuslara; "Ankara'ya dönüşümde B.M.M. Reisini meclis önünde asacağım" şeklinde konuştukları ve tehdidi işitenler arasında Yozgat Mebusu Süleyman Sırrı Bey'in de bulunduğu ifade edilerek, Çerkes Ethem ve kardeşlerinin ilk dikkat çeken davranış ve uygulamaları açıklanmaktadır. ${ }^{3}$

Mustafa Kemal Paşa; tüm bu davranışlarına ve aleyhlerinde alınan istihbarata karşın, Ethem ve Tevfik kardeşlerin daima istifade edilebilir bir durumda bulundurulmasinı tercih ettiklerini, bunları Yozgat'tan sonra Ankara üzerinden Kütahya bölgesine yolladıklarını beyan etmektedir. Bütün bu gelişmelerin yanında, Yeşil Ordu Cemiyetinin de artık zararlı bir mahiyet aldığının anlaşılması üzerine, cemiyetin kapatılması yolları araştırılmış; ancak tamamen ortadan kaldırılması o an için mümkün olamamıştır. $\mathrm{Bu}$ durumun önemli bir gerekçesi olarak, cemiyet kurucularından Reşit, Ethem ve Tevfik Beylerin faaliyetleri gösterilmektedir. Bunların ayrıca Eskişehir'de çıkarttıkları, "Yeni Dünya Gazetesi" ile de fikir ve amaçlarını saldırgan bir şekilde yaydıkları açıklanmaktadır."

\section{Düzenli Orduya Geçiş Esnasındaki Faaliyetleri:}

Anadolu ortasında yaşanan isyanlar hakkında bilgi verilirken; düzenli ordu teşkiliyle ilgili mecliste iki ayrı bakış açısının çatıştı̆̆1; takip edilen düzenli orduya geçiş yoluna karşı, milis teşkilatının oluşturulması fikrinin de yaygın bir görüş olarak ortaya çıktığı; bu bağlamda Reşit, Ethem ve Tevfik kardeşlerin Kütahya civarında ellerindeki birlikleri Kuvayı Seyyare olarak

\footnotetext{
${ }^{3}$ Nutuk, Ankara, 1927, s. 345-347.

${ }^{4}$ Nutuk, Ankara, 1927, s. 346-347.
} 
adlandırarak, bu yaygın görüşün en hararetli destekçisi olarak faaliyet göstermeye başladıkları belirtilmektedir. ${ }^{5}$

Garp Cephesi'nde ordu ve halk arasinda etkili bir propaganda sürdürülmektedir. Çok yoğun olan bu propagandanın ana teması; "Ordudan fayda yoktur kaldırllsın! Hepimiz Kuvayı Milliye olalım...” şeklindedir. Kuvayı Milliye halinde önemli bir konumda olan Ethem Bey ve müfrezeleri de etkinliklerini artırarak, herkes üzerinde bir üstünlük tesis etmişlerdir. Garp Cephesi Kumandanının, Gediz civarında müstakil bir durumda bulunan Yunan firkasina taarruz fikrinin Erkan-1 Harbiye-i Umumiye Riyasetine teklif edildiği, bu teklifte Ethem ve kardeşlerinin önemli etkisinin olduğu sanılmaktadır. ${ }^{6} \mathrm{Bu}$ harekatın, Türk Erkan-1 Harbiye-i Umumiyesi'nin karş1 çıkmasına rağmen, Garp Cephesi Kumandanının inisiyatifiyle yapıldığı; ancak başarısızlıkla sonuçlandığı üzerinde durulmaktadır. Ortaya çıkan başarısızlığın, Ethem ve kardeşleri tarafından düzenli ordu birliklerine yüklenmesi yolunda yoğun propagandaya başvurdukları açıklanmaktadır. ${ }^{7}$

4 Eylül 1920 tarihinde, Tokat Mebusu Nazım Bey'in, meclis tarafindan Dâhiliye Vekâlet'ine seçilmesiyle ilgili bölümde; Mustafa Kemal Paşa'nın, Nazım Beyi önceki faaliyetleri nedeniyle onaylamadığı, makamına kabul etmediği ve bunun gerekçeleri izah edilmektedir. Aynı yerde, her ne kadar Çerkes Ethem ile ilgili bir husus geçmese de, Çerkes Ethem'in hatıralarında Nazım Bey ile ilgili gelişen olaylar ve görevden istifasına kadar geçen safha yer almaktadır. ${ }^{8}$

İsmet Paşa'nın Garp Cephesi Kumandanlığına atanmasıyla ilgili bölümde; Garp Cephesi Kumandanı Ali Fuat Paşa'nın görevden alınışı ve Moskova sefirliğine gönderilişi, Garp Cephesi Kumandanlığına İsmet Bey'in, Cenup Cephesi Kumandanlığına Refet Bey'in getirilişi hakkında ayrıntılara yer verilmektedir. ${ }^{9}$ Ethem'in hatıralarında görüleceği üzere, bu görev değişikliğine ilişkin, Kuvayı Seyyare bakımından ortaya çıkan hassasiyet önemli bir yer alacaktır.

Mustafa Kemal Paşa, 13 Kasım 1920 tarihli bir telgrafin, Ethem Beyin yakın bir arkadaşı tarafından, Eskişehir'den çekildiğinden bahsetmektedir. $\mathrm{Bu}$ telgrafin içeriğinde; Ethem Beyin, Ali Fuat Paşa ile birlikte Rusya'ya gitmesi söylentisinin, cephede ve geri bölgedeki halk tarafindan olumsuz olarak algılandığı; bu gibi kişilerin ülkeden uzaklaştırılmasıyla, halkın

${ }^{5}$ Nutuk, Ankara, 1927, s. 362-363.

${ }^{6}$ Nutuk, Ankara, 1927, s. 363.

${ }^{7}$ Nutuk, Ankara, 1927, s. 364-366.

${ }^{8}$ Nutuk, Ankara, 1927, s. 366.

${ }^{9}$ Nutuk, Ankara, 1927, s. 368. 
Mustafa Kemal Paşa'nın diktatörlüğünü ilan edeceği endişesine kapıldığı yer almaktadır. Mustafa Kemal Paşa ise; aslında Ethem ve kardeşlerinin Türkiye'den uzaklaştırılması için Ali Fuat Paşa'ya görüşünü bildirdiğini; ne cephenin, ne de halkın bu durumla ilgilenmediğini, eğer kendisi diktatör olmak isterse, Ethem ve onun gibilerin buna engel olup olamayacağ hususunun da dikkate değer bir durum olduğunu vurgulamaktadır. ${ }^{10}$

İsmet Paşa'nın Garp Cephesinde faaliyete başlamasıyla birlikte Ethem Bey'de rahatsızlığını beyan ederek Ankara'ya geldi ve uzun süre burada kaldı. Ethem'in yokluğunda kardeşi Tevfik Bey Kuvayı Seyyare birliklerine vekâleten komuta etti.

$\mathrm{Bu}$ dönemde Karakeçili namında gizli bir müfrezenin teşkil edildiği, cephe kumandanı tarafından tesadüfen öğrenildi. Tevfik Bey, cephe kumandanının bu müfrezeyi denetleme isteğini reddetti. Tevfik Bey artık cephe kumandanının vermiş olduğu emirleri dinlememeye başladı ve Kuvayı Seyyarenin diğer birliklerden ayrılması için kendiliğinden "Umum Kuvayı Seyyare ve Kütahya Havalisi Kumandanlığı" şeklinde bir düzenleme yaptı. 21 Kasım 1920 tarihinde verdiği raporda hayali bir düşman firkasının ilerlediği, Türk halkının da düşmanı bölgelerine davet ettiği hakkında asılsız bir rapor/bilgi verdi. Tevfik Bey, cephe kumandanının verdiği tüm emirlere itiraza başladı. Cephe kumandanının yaptığı düzenlemelere, atamalara karşı çıktı, hayali düşman birlikleri rapor etti. Bu raporların cephe kumandanı tarafindan ciddiye alınması ve tedbir geliştirmesi üzerine de bu tedbirleri boşa çıkarmaya çalıştı. Birliklerin ihtiyacı için geliştirilen tedbirleri kabul etmeyerek, kendi usulsüzlüklerini sürdürdü. ${ }^{11}$

Bursa Cephesi'nde ise, düşmanın bir faaliyeti başladığ 1 sırada, cephe kumandanının Tevfik Bey’le görüşmek üzere başvurmasına karşın, Tevfik Bey muharebe raporlarını Ankara'ya gönderdiğini beyan etti. Cephe kumandanı bu defa Ethem Bey'e müracaat ederek bilgi almaya çalışırken; Tevfik Bey, cephe kumandanının emrine aykırı olarak İstiklal Mahkemelerini dikkate almaz ve kendi uygulamalarına devam eder. $\mathrm{Bu}$ arada daha ilginç bir gelişme olur. Cephedeki gelişmelere ilişkin raporlar, Ethem Bey vasıtasıyla Mustafa Kemal Paşa'ya iletilmeye başlanır. Bunun üzerine Mustafa Kemal Paşa da cephedeki gelişmeler hakkında, neden cephe kumandanına bilgi verilmediği, bunun bir yanlış anlaşılmadan mı kaynaklandığı şeklinde Tevfik Bey'e bir mesaj yazar, ancak herhangi bir cevap alamaz. Bu gelişmeler üzerine Ethem Bey, Mustafa Kemal Paşa'ya; kardeşi Tevfik Bey ile İsmet Paşa arasında yanlış anlaşılmadan kaynaklanan bir irtibatsızlığın yaşandığ 1 hakkında bir telgraf çeker. Bu arada cephe kumandanı tarafından halka hitaben bir beyanname yayınlanır, ancak Tevfik

${ }^{10}$ Nutuk, Ankara, 1927, s. 373.

${ }^{11}$ Nutuk, Ankara, 1927, s. 374-376. 
Bey bu beyannamenin kendileri tarafından tanınmadığını, cephe kumandanının namuslarıyla oynadığı gibi garip beyanlarda bulunmaya başlar. $^{12}$

Garp Cephesinde yaşanan bu gelişmeleri değerlendiren Mustafa Kemal Paşa'nın, Ethem ve kardeşleri hakkındaki genel kanaati şu şekildedir:

Ethem ve Tevfik kardeşler ile kendileriyle aynı fikirde olan bazı arkadaşları milli hükümete karşı isyan kararı vermişlerdir. Bu kararlarını uygulama alanına koyabilmek için cephede Tevfik Bey, çeşitli bahaneler arayarak kuvvetlerini cepheyi terk suretiyle toplamaktadır. Ankara'da ise, Ethem Bey ile kardeşi Reşit Bey ve daha bazıları siyaseten çalışmaktadır. İsyan planında başarılı olabilmek için her şeyden önce buna karşı en önemli engel olarak gördükleri Garp Cephesi Kumandanını itibarsızlaştırmayı, makamından ederek ordu üzerinde hâkimiyet kurmayı tasarlamaktadırlar. Ondan sonra da, meclis kamuoyunu tamamen kendi lehlerine çevirerek kumandan veya vekil veya hükümetin ortadan kaldırılmasını sağlayacaklardır. $\mathrm{Bu}$ konuda kendisinde bir şüphe kalmamıştır. Ancak Mustafa Kemal Paşa'nın da bu isyana karşı cephede ve Ankara'da gereken tedbirleri aldığ1; isyandan çekinmediği; isyanın bastırılabileceğine emin olduğu, fakat gene de bunların nasihatle itaate zorlanması düşüncesinde olduğu; bunun mümkün olmaması halinde kamuoyunda infiale neden olmadan durumu çözebileceğine inandığını belirten hususlar nutukta yer almaktadır. Tüm bu düşünceler çerçevesinde; Ankara'da bulunan Ethem ve Reşit Beyleri ve diğer bazı zevatı beraber alarak Eskişehir'e gitmeye ve orada İsmet Paşa ile buluşarak konuşmaya ve anlaşmaya 2/3 Aralık gecesinde karar vermiştir. Ethem Bey'i gerekirse zorla götürmek için gerekli tedbirleri aldığını; 3 Aralık akşamı, Ethem ve Reşit Beyler ile Kazım Paşa, Celal Bey, Kılıç Ali Bey, Eyüp Sabri Bey, Hakkı Behiç Bey, Hacı Şükrü Bey beraberlerinde olmak üzere yola çıktıklarını; 4 Aralık 1920 sabahı Eskişehir'e ulaştıklarını, İsmet Bey'in Bilecik'te olması nedeniyle oraya gitmeye karar verdiklerini, bu arada Eskişehir'de duraklama esnasında Ethem Bey'in trenden ayrıldığını, o olmadığı için Bilecik'e gitmeye gerek olamadığından İsmet Bey'in Eskişehir'e davet edilmesinin kararlaştırıldığını açıklamaktadır. ${ }^{13}$

\section{Çerkes Ethem ve Kardeşlerinin İkaz Edilmesi}

4 Aralık 1920 akşamı, Eskişehir'de İsmet Bey'in karargâhında; Kazım Paşa, Celal Bey, Hakkı Behiç Bey ve Mustafa Kemal Paşa toplandılar. Reşit Bey, Ethem'in yokluğu hakkındaki soruya "Şu an kuvvetlerinin başındadır"

\footnotetext{
${ }^{12}$ Nutuk, Ankara, 1927, s. 376-379.

${ }^{13}$ Nutuk, Ankara, 1927, s. 379-381.
} 
cevabını verdi. İsmet Bey ise, mevcut durum hakkında bilgi vererek, Tevfik Bey'in serkeşçe davranışları hakkında açıklamalarda bulundu. Reşit Bey kardeşi adına soruları cevaplandırırken; çok kaba ve saldırgan bir tavırla kardeşlerinin birer kahraman olduğunu, hiç kimsenin emri altına girmeyeceklerini, herkesin bunu böyle kabul etmesi gerektiğini söyledi. Daha da ileri giderek, ordu, disiplin, komuta ve hükümet kavramlarıla ilgili ileri sürülen görüşlere kulak vermemesi üzerine, Mustafa Kemal Paşa; TBMM'nin ve Hükümetin Başkanı olarak Garp Cephesi Kumandanına durumun gereğini yerine getirmek üzere yetkisini kullanmasını emretti. İsmet Paşa da her komutan gibi üzerine düşen yetkiyi gerektiği şekilde kullanma yeteneğinde olduğunu ifade etti. Reşit Bey karşılaştığı kesin tavır üzerine, kardeşlerinin yanına giderek uzlaşma çarelerine başvuracağını belirtti. Sonuçta Reşit Bey ve Kazım Paşa'nın Kütahya'ya giderek Ethem ile görüşmesi kararlaştırılır. Mustafa Kemal Paşa, bu durumu tamamen zaman kazanmaya yönelik bir davranış olarak değerlendirmektedir. ${ }^{14}$

Mustafa Kemal Paşa, 5/6 Aralık gecesi Reşit Bey'den durumun düzeltilmekte olduğuna ilişkin bir telgraf almıştır. Ancak bu telgrafin artık kendisi için bir önem taşımadığını ifade etmektedir. 9 Aralık tarihli telgrafta ise Tevfik ile olan meselenin iyi bir sonuca bağlandığ 1 belirtilmektedir. Mustafa Kemal Paşa aynı gün bu defa Ethem Bey'den bir telgraf almıştır. Bu telgrafta; İsmet Paşa'nın meseleyi maksatlı ve zamansız olarak ortaya çıkardığı, Mustafa Kemal Paşa'nın gelişmeler karşısında boşuna kuruntuya düştügünden bahsedilmektedir. Mustafa Kemal Paşa ise bu telgrafa verdiği yanıtta; “...Kuruntuya değil, kararsızlı̆̆a düştüğ̈̈nü, genel durumun uyum ve düzenini bozmaya hiç kimsenin göz yummaması gerektiğinden..." bahsetmektedir. ${ }^{15}$

\section{Mustafa Kemal Paşa'nın Durum Değerlendirmesi}

Mustafa Kemal Paşa'ya göre; gerçekte mesele çözülmemiştir. Ethem ve kardeşleri zaman kazanmak amacıyla, hükümeti yanıltmaya çalışmaktadırlar. Amaçları mümkün olduğu kadar kuvvet toplamak, Düzce'de bulunan Sarı Efe kuvvetleriyle, Lefke'de bulunan Gökbayrak Taburunun kendilerine katılmasını ve Demirci Mehmet Efe'nin de kendileriyle beraber isyan etmesini sağlamak; bir yandan da cephe kumandanlarını değiştirmek, ordudaki subay ve erlerin kendilerine karşı koymamaları için propagandaya firsat bulmaktır. Yani başlangıçtaki itaatsizlik aynen devam etmektedir. $\mathrm{Bu}$ arada Ethem Bey'in, ellerinde özel şifreler bulunan memurları Konya, Ankara, Haymana dâhil her tarafta, silah ve hayvan toplamaya devam

\footnotetext{
${ }^{14}$ Nutuk, Ankara, 1927, s. 381.

${ }^{15}$ Nutuk, Ankara, 1927, s. 383.
} 
etmektedirler. Kuvay1 Seyyare kumandan vekili Tevfik Bey, cephe kumandanına hitaben saygısız telgraflar çekmekte; Ethem Bey ise cephe kumandanına çektiği telgraflarda muhaberenin engellendiği konusundan bahsetmektedir. Mustafa Kemal Paşa, Kuvayı Seyyarenin adeta iki ayrı kumandan tarafından idare edildiğini örneklerle açılamakta, bunların yanında Çerkes Ethem'in hükümet kanunlarına aykırı hareketlerine yer vermektedir. $^{16}$

\section{Sonuna Kadar Gelișmeler:}

13 Aralık 1920 tarihinde Ethem Bey ile Ankara'da bulunan kardeşi Reşit Bey arasında uzun bir telgraf görüşmesi oldu. Ethem Bey şunları söylemektedir: "Konunun mutlaka mecliste görüşülmesini sağlayınız. Sar Efe denilen Edip'in kendi müfrezesi ile Gökbayrak Taburuna katılmast için haber gönderiniz. Meclis vasitaslyla kumandanlart görevden çektiriniz. Meclis kararı olmasa bile bir yolunu bulup bunu hemen sağlayınız. Patlatacă̆ım bombaları, ta İnilizler işitecek ve bunun patlaması da pek yakındır..." Reşit Bey'in ise verdiği cevaplarda dikkat çekenler şu şekildedir: "Kuvayı Seyyare düşmana karşı savunma yapmasın, bunu diğer firkalara biraksin. Edip'le bizzat haberleşmen gerekir... Buna engel olunduğu takdirde Cephe Kumandantyla yeniden irtibatı kesin..." Reşit Bey, bu telgrafları daha sonra Mustafa Kemal Paşa'ya göndermiş, Mustafa Kemal Paşa kendisini yanına çağırttı̆̆ında ise cephe kumandanlarının değiştirilmesini teklif etmiştir. Ancak bu teklifinin kabul edilemeyeceği kendisine açıklanmıştır. Mustafa Kemal Paşa bu gelişmeleri şöyle değerlendirmektedir; Ethem ve kardeşleri cephede bulunan komutanları beğenmemekte ve onların emirlerine uymamaktadırlar. Bakanlıkları ve Hükümeti tanımayıp yalnız kendisine (Mustafa Kemal Paşa'ya) itaat etmektedirler. Meclisi de kendi isteklerine göre harekete geçireceklerini sanmaktadırlar. Yani özetle kendisine ve meclise karşı hoş görünerek, büyük bir gayretle hazırlıklarını tamamlamaya çalışmaktadırlar. Hatta Edip Bey ve müfrezesinin kendilerine katılması için Mustafa Kemal Paşa'yı aracı olarak kullanmaktan çekinmemektedirler. Bunun yanında Haymana'dan bile kuvvet toplamaya çalışmaktadırlar. ${ }^{17}$

Bu arada Demirci Mehmet Efe, Ethem Bey'le birleşmek üzere harekete geçmiş, ancak 15/16 Aralık 1920 gecesi Refet Bey süvarileri bu kuvvetleri dağıtmıştır. 20/21 Aralık gecesi Reşit Bey, Yeni Dünya Gazetesi çalışanlarıyla, ordu içerisinde propaganda yapmak üzere bir toplantı yapmıştır. Bunların içinden Hidayet Bey durumu Mustafa Kemal Paşa'ya

${ }^{16}$ Nutuk, Ankara, 1927, s. 383-385.

${ }^{17}$ Nutuk, Ankara, 1927, s. 385-387. 
ihbar etmiş ve ordu içinde propaganda amaçlı çalışmalarının olduğunu itiraf etmiştir. $^{18}$

Kazım Paşa da, Reşit Bey'le beraber Kütahya'da Ethem'le yaptığı görüşmede, Ethem'in şu görüşlerini Mustafa Kemal Paşa'ya iletmiştir;

“Ankara'daki Hükümet gayeyi gerçekleştirecek durumda ve güçte değildir. Bu hükümete karşı uyuşuk davranmamı doğru olmaz...Silahla karşı koymamızın mahiyetini kötüye yoracaklardır. Fakat sonunda başarırsam herkes bana hak verecektir...Refet Bey'le aramızda bir izzet-i nefis meselesi geçmiştir. Mustafa Kemal Paşa, Refet Bey’in haysiyetine değer vererek, bizimkini kırıyor. Herhalde Refet Bey'i önüme katarak Ankara'ya kadar kovalamak isterim. Ölürsem de bu takip de öleyim...Biz çoktan bu işi yapardık. Fakat Reşit'in Ankara Meclisi'ndeki durumu bizi yanıltmıştır. Meclisin ne önemi ve hükmü vardır?"

Kazım Paşa da bu görüşleri dinledikten sonra telkin yoluyla bunları yatıştırmaya ve Ethem'i 1lımlı bir duruma getirmeye çalışmıştır. ${ }^{19}$

Mustafa Kemal Paşa, Reşit Bey’i meclisin otoritesini bozucu faaliyetlerine son vermesi için heyet huzurunda ikaz etmiştir. Bu gelişme üzerine, Reşit Bey'in bazı mebuslarla birlikte kardeşlerinin yanına giderek, nasihatlerde bulunulması teklifi kabul edildi. Gidecek heyete Kuvayı Seyyareye, hükümetin son ve kesin istekleri olan aşağıdaki hususları bildirmesi kararlaştırıldı:

"Kuvayl Seyyare; diğer birlikler gibi emir ve komutaya tam olarak uyacak ve kanun dışı her türlü taşkınlıktan kaçınacaktır... kuvvetini artırmak için kendiliğinden hiçbir yerde, hiçbir şekilde adam toplamayacak ve bu maksatla gönderdiği adamların faaliyetine derhal son verecektir. Asker ihtiyacı öteki birliklerde olduğu gibi yapllacak müracaat üzerine Cephe Kumandanlı̆̆ınca sağlanacaktır... kaçaklarını yakalatmak için doğrudan doğruya adamlar görevlendirip, göndermeyecek, kaçaklar, diğer birliklerde olduğu gibi Cephe Kumandanliğınca takip ettirilecek ve yakalattırlacaktır...mensuplarının ailelerine bakmak üzere bazı yerlerde bulundurduğu irtibat subaylarının kimler olduğu hükümetçe bilinecek ve bu irtibat subaylarının ellerinde bulunan şifrenin bir sureti de bize verilecektir. Bu şartlar yerine getirildiği takdirde, Kuvayı Seyyare, şimdiye kadar olduğu gibi belirli bir kadro dâhilinde yine görevine devam edecektir. "20

\section{Çerkes Ethem'e Gönderilen Son Nasihat Heyeti:}

Nasihat Heyetinde; Reşit Bey'le beraber, Celal, Kılıç Ali, Eyüp Sabri ve Vehbi Beyler vardır. Heyet, 23 Aralık 1920'de Ankara'dan hareket

\footnotetext{
${ }^{18}$ Nutuk, Ankara, 1927, s. 387-388.

${ }^{19}$ Nutuk, Ankara, 1927, s. 388.

${ }^{20}$ Nutuk, Ankara, 1927, s. 389-390
} 
etmiş, 24 Aralık'ta 16.45 'te Kütahya'ya ulaşmıştır. Bu esnada; Ethem ve Tevfik Beylerin, Cephe Kumandanının haberi olmaksızın bölgelerindeki ordu birliklerini cepheye dağıtarak, Kuvayı Seyyarenin ağırlıksız erlerini Gediz'de ve Pehlivan Ağa Müfrezesini Kütahya'da topladıkları haberi geldi. 25/26 Aralık tarihinde bu durum hakkında bilgi verilmesi heyette bulunan Celal Bey'e iletildi. Celal Bey de; “...müsterih olunmasını, durumun kötüye yorulmamasını, ertesi gün yapılacak görüşmelerden sonra teferruatlı cevap verilebileceğini" bildirdi. Mustafa Kemal Paşa bu cevabı; giden heyetin aldatılmakta olduğu şeklinde yorumlamaktadır. Ancak hem heyetin, hem de Ethem ve Tevfik Beylerin duyulan endişeden kuşkulanmamaları için çok olumlu bir telgraf çekmiştir. Heyet de, 26/27 Aralık 1920'de ortak imzalı ve teferruatlı bir telgrafi Ankara'ya gönderdi. Bu telgraftaki önemli hususlar özetle şu şekildedir:

"Birliklerin almış olduğu güvenlik tedbirleri, etkili savunmanın sağlanmasına yöneliktir. Durumun normale dönmesiyle alınan tedbirlerden vazgeçilecektir... Düşmanca hareketlerle karşılaşılmadıkça memleketin gelecekteki selameti için ve Mustafa Kemal Paşa'ya besledikleri içten bağlılık dolayısıyla her türlü fiili hareketlerden kaçınacaklarına dair en büyük yeminlerle söz vermişlerdir... Kuvayı Seyyareye katılmak üzere Konya ve Alaca'dan gelenler ve bu esnada tutuklananlara engel olunmamasl, Kuvay Seyyareye para verilmesi için Kütahya Mutasarrıflı̆̆ına emir verilmesi, karşılıklı güven ve itimadın gerçekten kurulması ve devamlıliğ için Fahrettin ve Refet Bey'in cepheden uzaklaştırılması..."

Mustafa Kemal Paşa'nın kanaati ise; “...ya heyet gerçekten tutuklanmıştır, ya da hepsi birden belirtilen hususlart idrak edemeyecek niteliktedirler..." şeklindedir. Heyete, telgrafin ertesi gün Bakanlar Kuruluna sunulacağı bildirildi. Aynı anda İsmet Bey ve Refet Bey'e de kuvvetlerini toplu ve tedbirli bulundurmaları ikaz edildi. Bakanlar Kurulundan çıkarılan bir kararnamede; söz konusu mesaj belirtildikten sonra; Kuvayı Seyyarenin kayıtsız şartsız B.M.M. kanunlarına, hükümetin koyduğu düzen ve emirlere uymakla yükümlü olduğu; bağlı bulunduğu komutanlık vasıtasıyla ilgili makamlarla ilişki kurması gerektiği belirtildi. ${ }^{21}$

27 Aralık'ta Heyete, görevlerinin sona erdiği ve geri dönmeleri gerektiği bildirildi. 28 Aralık'ta Heyetten alınan mesaj ise oldukça iyimser nitelikte olup, durumun memleketin menfaatleri çerçevesinde değerlendirildiği, konunun sürüncemede kalmasının uygun olmayacağ 1 şeklindedir. Bu mesaja Mustafa Kemal Paşa 28 Aralık'ta tüm safahatı açıklayıcı bir telgrafla cevap vermiş ve bu telgrafın sonunda şu ifadede

${ }^{21}$ Nutuk, Ankara, 1927, s. 390-393. 
bulunmuştur; “...Yüksek görüşleriniz hiçbir şekilde kötüye yorumlanmış değildir... Benim bir buçuk aydır şahsi ve özel gayret ve teşebbüslerimle ve büyük bir samimiyetle yaptığım çalışmaların ne yazık ki takdir edilmemiş olduğunu görüyorum. Şüphesiz bu konunun çözüm ve takibini sorumlu ve ilgili makamlara bırakmış bulunuyorum." Heyet mevcut durumu meclise açıklayarak, kendilerine daha yararlı olabileceklerine Ethem ve kardeşlerini inandırarak ellerinden kurtulmuş, Reşit Bey ise orada kalmıştır. ${ }^{22}$

\section{Nutuk'ta Çerkes Ethem Hadisesinin Sonu:}

Mustafa Kemal Paşa; asi Ethem ve kardeşlerine karşı fiili harekete geçilme emrinin verilmesini şu sözlerle dile getirmektedir:

"Efendiler; askeri harekâtt, çapulculuktan; devlet kurup yönetmeyi, şunun bunun çocukların dağlara kaldırmak haydutluğundan ibaret zanneden; şarlatanlıklartyla, yaygaralarlyla bütün bir Türk vatanını bezdiren ve Türk milletinin Büyük Meclisini kendileriyle uğraştıran, utanmaz, haddini bilmez, küstah ve herhangi bir düşmanın boğazı tokluğuna casusluğunu, uşaklığını yapacak kadar aşağıllk, bayă̆ yaratıllş̧ta olan bu kardeşleri, ellerindeki bütün kuvvetler ve dayandıkları düsmanlarla birlikte yola getirmek ve ortadan kaldırmak suretiyle, inkalap tarihimizde etkili bir ibret örneği vermek zaruri görüldü...." 23

Mustafa Kemal Paşa, Çerkes Ethem birliklerinin Türk düzenli ordusu karşısında darmadağın olduklarını belirttikten sonra; Ethem'in İstanbul'da Sadrazamlık makamına çekmiş olduğu telgrafa yer vermiştir. Ayrıca telgraf içinde geçen protesto yazısının, mecliste ne yazık ki okunmak zorunda kalındığını; Türk ordusunun Kütahya'ya girerken kendisinin mecliste milletvekilleri tarafindan sorguya çekilmekte olduğunu; bazı mebusların Ethem Bey kuvvetlerine büyük önem vererek, kendisini suçladıklarını; 29/30 Aralık günleri gizli ve açık celselerde duruma tüm belgelerle açıklık getirmesine rağmen, yoğun propaganda ve kamuoyunun yanıltılmas1 amacıyla yapılan faaliyetlerin etkisinde kalan mebusların bir türlü gerçeği anlamak istemediklerini belirtmektedir. Nihayet, meclisin heyecan ve kararsızlığını giderecek inandırıcı bir konuşma yaparak, gizli oturumlardaki görüşmeleri, çarpışmaların fiili sonuçlarını beklemek üzere kapattıklarını açılamaktadır. ${ }^{24}$

Mustafa Kemal Paşa, 5 Ocak 1921 günü birliklerin Gediz’i işgal ederek, Ethem ve kardeşleri hadisesine son verdiklerini, onların da düşman saflarına geçerek hak ettikleri yeri aldıklarını belirtmektedir. 8 Ocak 1921 günü

${ }^{22}$ Nutuk, Ankara, 1927, s. 394-395.

${ }^{23}$ Nutuk, Ankara, 1927, s. 395.

${ }^{24}$ Nutuk, Ankara, 1927, s. 395-396 
mecliste konuşurken Ethem, Tevfik ve Reşit Beyler ifadesini kullandığ 1 zaman, meclisten "Paşa Hazretleri artık bey demeyiniz..." seslerinin yükseldiğini, aynı gün Reşit Bey'in de milletvekilliğinin kaldırıldığını açıklamaktadır. ${ }^{25}$

\section{Çerkes Ethem'in Hatıralarında Geçen Olaylar:}

\section{Çerkes Ethem'in Kimliği:}

Çerkes Ethem; Bandırma'da bir çiftlik sahibi olan Ali Bey isminde bir zatın oğludur. 1886'da doğan Ethem, Bakırköy Küçük Süvari mektebinden zabit vekili olarak terhis oldu. Zabit vekili olarak Çürüksulu Mahmut Paşa Kolordusunun muhafız bölüğünde bulundu, bu kolordunun Balkan Harbi'nde Bulgarlarla yaptığı Congri Muharebesine katıldı, kolordunun karargâhı ile Çatalca'ya döndü. Kardeşleri Reşit ve Tevfik Beylerin Harbiye'den izine geldikçe beraberlerinde getirdikleri askeri kitaplardan nazari bilgiler edindi. Bunlardan Reşit Bey binbaşıllı̆ga, Tevfik Bey ise yüzbaşılığa kadar yükseldi. Her ikisi de ittihatçıydı. Ethem Birinci Dünya Savaşı esnasında Teşkilat-ı Mahsusa'ya katıldı. Önce Ruslara karşı harekâtta, daha sonra İran güneyinde İngiliz bölgesinde ve Afgan Seferi Heyeti içerisinde yer aldı. Mondros Mütarekesi'nin ilan edildiği günlerde ise Bandırma'dadır. ${ }^{26}$ Çerkes Ethem, Milli Mücadele'ye destek olan milis kuvvetlerini oluşturmadan evvel Bandırma ve Manyas bölgelerinde önemli bir güce sahip olan Manyaslı eşkıya Şevket ve Çolak İbrahim'in yanında bulundu. 13 Şubat 1919 günü İttihatçı İzmir Valisi Rahmi Bey’in oğlunu elli bin liralık fidye karşılığı kaçırdı ve dikkatleri üzerinde toplamaya başladı. ${ }^{27}$

Mütareke sonrası Ege Bölgesinde meydana gelmesi muhtemel olayları düşünerek, 25 Mayıs 1919'da Ethem ve kardeşlerini ziyaret eden Rauf Bey, onlara Salihli'de teşkilatlanma çalışmalarına başlamalarını, bu tür faaliyetleri için eski Teşkilat-1 Mahsusa Reisi Kuşçubaşı Eşref Bey'in çiftliğinde bulunan para, silah ve diğer malzemelerden yararlanabileceklerini söylemiştir. Bunun üzerine Ethem, Salihli'de teşkilat oluşturma çalışmalarına başlamıştır. ${ }^{28}$

\section{Çerkes Ethem'in Yozgat İsyanı Öncesi Faaliyetleri:}

Ethem, Milli Mücadele'nin başlangıcında yerel ve bölgesel kurtuluş çarelerinin aranması esnasında teşkil edilen, Kuvayı Milliye teşkilatlarının

\footnotetext{
${ }^{25}$ Nutuk, Ankara, 1927, s. 398.

${ }^{26}$ Çerkes Ethem, Çerkes Ethem'in Hatıraları, Dünya Yayınları, İstanbul, 1962, s. 10-12.

${ }^{27}$ Ethem, Hatıralar, s. 12, d.n. 2.

${ }^{28}$ Cemal Kutay, Çerkes Ethem Tamamlanmış Dosya, Özgür Yayınları, İstanbul, 2004, s. $37-39$
} 
içinde Kuvayı Seyyare adı altında en güçlü birliği elinde bulundurmaktadır. $\mathrm{Bu}$ birliklerle bir yandan Yunan işgallerine karşı direniş, diğer yandan da ülke içinde yaşanan özellikle, Düzce, Bolu, Hendek isyanlarında, Adapazarı'nda Anzavur Harekâtında önemli başarılar göstermiştir. ${ }^{29} \mathrm{Bu}$ başarılarının, Mustafa Kemal Paşa ve Cephe Komutanlarınca takdir edildiği şu telgraflarda görülmektedir:

“Ada'da Kolordu Kumandanı Ali Fuat Paşa Hazretlerine, Ankara, 2 Mayls 336;

Ethem Bey kuvvetlerinin Eskişehir'de toplanmalarl hususundaki mütalaalarınıza iştirak ederiz. Başarıları ve Hizmetleri kurtuluş tarihimizde en parlak satırlar işgal edecektir. Pek samimi tebrik ve teşekkürlerimizin bütün millet meclisi namına kendilerine iblağl hususunda delalet-i devletlerinizi rica ederiz efendim.

\section{Mustafa Kemal"}

"Düzce'de Kuvayı Tedibiye Kumandanı Ethem Beyefendiye, 12-13 Mayls 336;

Büyük Millet Meclisi Riyaset-i Celile'sinden gelen tebrik ve teşekkürleri taşıyan telgraf suretini aynen iblağ ederim Ben de sizi tebrik eder, vatana daha büyük hizmetlerde bulunmanızı temenni ederim.

\section{Adada Kolordu Kumandanı Mirliva Ali Fuat", 30}

\section{Çerkes Ethem Yeşil Ordu İlişkisi:}

Çerkes Ethem hatıralarının önemli bir bölümünde Ankara'da; mebusların kendisini s1k sik ziyaret ettiklerinden bahsetmektedir. $\mathrm{Bu}$ ziyaretler esnasında konuşulan konular ayrıntılı olarak hatıralarında yer almamıştır. Aksine Ethem cemiyete katılmadığını özellikle şu sözlerle ifade etmektedir: "...Yeşil Ordu namında, Kuvayı Milliyenin başından sonuna kadar, herhangi bir safhasl arasinda bu nam ve isimde, resmi, hususi, gizli, açık bir teşkilat ve teşekkülün kaydına ve izine tesadüf edilemez..." 31

Ethem'in bu tespitinin ne kadar gerçekçi olup olmadığını, Yozgat isyanını bastırmak üzere Ankara' da bulunduğu günlerde; "Ankara'da samimi birçok gaye arkadaşları da bulmuştum ki, müsait bir zamanın gelmesini can ve gönülden istiyorlar ve dua ediyorlardı..." 32 şeklinde sarf ettiği

${ }^{29}$ Ali Fuat Cebesoy, Milli Mücadele Hatıraları, Temel Yayınları, İstanbul, 2010, s. 415-508.

${ }^{30}$ Ethem, Hatıralar, s. 50-51.

${ }^{31}$ Ethem, Haturalar, s. 59.

${ }^{32}$ Ethem, Hatıralar, s. 61. 
sözlerinden yorumlanabilir. Burada belirtilen ve elverişli bir zamanın gelmesini kollayan samimi gaye arkadaşlarının, Yeşil Ordu Cemiyeti mensuplarından olduğunu değerlendirmek mümkündür. Çerkes Ethem, 1920 yılında Kuvayı Milliye'nin en güçlü birliklerini elinde bulundurmaktadır. Aynı dönemin siyasi ortamında, yeni düşünceleri savunan ve iktidar için emelleri olan Yeşil Ordu Cemiyeti üyelerinin Ethem'i yanlarına çekmek önemli bir firsattır. Böylece elde edecekleri askeri güçle Mustafa Kemal Paşa ve yakın çevresine karşı bir üstünlük elde etmeyi tasarladıkları düşünülebilir.

Çerkes Ethem'in Bolşevik propagandasından oldukça etkilendiğini; Sovyet Rusya yöneticilerinin, kendisini tuttuklarını, Bolşevikliğe karşı duyduğu ilgi şu sözlerinden anlaşılmaktadır:"Bolşevizm dünyayı zapt edecektir. Bunu gerektiği şekilde kabul edip karşılayacak olursak, millet herhalde bahtiyar olacaktır. Bolşeviklik istikbalimiz için çok yararlı ve yerinde olacaktır. Buna emin olunuz. Bolşevizm şimdi yurdumuzu kurtarmakta, gelecekte de insanların hayat ve mutluluğunu koruyacaktır. "33 Sovyet Rusya taraftarlığını ise; “...Moskova yoldaşları, Türk ihtilal ileri gelenleri arasında daha ziyade beni emin buluyorlardı. Ve bu kanaatlerini açıkça ortaya koymuşlardı. Lenin ilk ilan ettiği, milletler hakkında hürriyet ve serbestiye ait yüksek ve çekici prensipler, yine onlar tarafindan cerh edilinceye kadar (çürütülünceye kadar) ben Sovyet dostluğunun hararetli ve samimi taraftarlarından bulunuyordum ... ${ }^{, 34}$ şeklindeki sözlerinden anlamak mümkündür.

Ethem'in Yeşil Ordu ile ilişkisi ve böylece cemiyetin eline silahlı bir gücün geçmesi ihtimali, Mustafa Kemal Paşa'nın elde ettiği istihbaratta da mevcuttur. ${ }^{35}$ Cemiyet, Mustafa Kemal'in adını kullanarak genişlemiş ve zararlı olmaya başlamıştır. Mustafa Kemal Paşa, cemiyetin kapatılması hakkında Cemiyet Genel Sekreteri Hakkı Behiç Beye gereken talimatı vermiş, ancak cemiyetin hemen kapatılmasının mümkün olamayacağ 1 anlaşılmıştır. Cemiyet faaliyetlerini yavaşlatmış ve Ethem'in daha tesirli olduğu Eskişehir bölgesine kaydırmıştır. ${ }^{36}$

Garp Cephesi Kumandanlığının, varlığından ancak 17 Kasım 1920'de tesadüfen haberdar olduğu, Karacaşehir'de konuşlanmış bir Karakeçeli Müfrezesi mevcuttur.(Nutuk, Sf. 374) Müfreze Ethem'in Kuvay1 Seyyaresine bağlıdır. Ethem tarafından bu müfreze "Bolşevik Taburu"

${ }^{33}$ Mustafa Yılmaz, Milli Mücadelede Yeşil Ordu, Kültür ve Turizm Bakanlığı Yay., No:783, Ankara, 1987, s. 112.

${ }^{34}$ Ethem, Hatıralar, s. 109.

${ }^{35}$ Nutuk, Ankara, 1927, s. 346-347.

${ }^{36}$ Yılmaz, Milli Mücadelede Yeșil Ordu, s. 113. 
olarak anılmaktadır. Ethem, söz konusu müfrezeye hatıralarında şu şekilde değinmektedir.

“...Bolşevik Taburu hakkinda da izahat vereyim; atl piyade namı verilen hafif süvari teşkilatına haiz Kuvayı Seyyare Fırkası ve kitaları arasında, Bolşevik Taburu adinı alan dolgun mevcutlu bir piyade taburumuz vardl. 700 mevcutlu bu milis kıtasını, ekseriyeti Karakeçili Aşireti efradından mürekkep olarak, Eskişehir Müdafaa-i Milliye Teşkilatı kurmuş, emrimize göndermişsi. Taburun kumandanı, Yüzbaşı İsmail Hakkı Efendi, harpçi olmaktan ziyade, hakikaten Bolşevik ruhlu, karşısındaki düş̧an ordusunu harp aleyhine teşvik kabiliyetinde birisiydi. Son zamanlarda muharebelerden bıkmış (düşman) askerlerini hükümetleri aleyhine isyana teşvik ediyordu. Kendisine bu yüzden fevkalade tahsisat vermekteydim. Tabura nam bu kumandan yüzünden verilmişti. ${ }^{, 37}$

$\mathrm{Bu}$ sözlerden İsmail Hakkı Bey'in yetişmiş bir propaganda uzmanı olduğunu değerlendirmek mümkündür. Her ne kadar Ethem, Yeşil Ordu Cemiyeti ile ilişkisini inkâr etse de; cemiyetin talimatnamesi esaslarını içeren ifadeleri farkında olmadan kullanmaktadır. (Çok iddialı bir değerlendirme olamamakla beraber; bu hatıraları kasitlı olarak kaleme alan bir teşkilatın da varlığı gözden uzak tutulmaması gereken bir varsayımdır.) Ethem cemiyetle olan bağını doğrudan doğruya yalanlamaktadır. Bu ise karşı propaganda tekniklerinin başında gelen bir yöntemdir. Hatıralarda buna özen gösterdiği görülmektedir. Tüm bunların yanında, Ethem çok genç yaşlardan itibaren Teşkilat-1 Mahsusa içinde görev yapmaya başlamıştır. Yani günümüzde Gayri Nizami Harp olarak adlandırılan özel savaş tekniklerini yaşayarak, tecrübeli liderlerin yanında öğrenmiştir. Gayri Nizami Harp teknikleri içinde propaganda ve karşı propaganda çok önemli ve öncelikli bir faaliyet alanı olarak uygulanmaktadır. Dolayısıyla bu tekniklere olan hâkimiyetine tüm hatıraları boyunca rastlamak mümkündür. Ethem bu yöntemleri zamanın koşullarına uygun olarak ustalıkla kullanmıştır. (Veya bu hatıraları kaleme alan teşkilat, kişi veya kişiler)

Cemal Kutay'ın aktardığı hatıralarda ise; Ethem, Yeşil Ordu ile ilişkisini şu şekilde inkâr etmektedir:

"Mustafa Kemal Paşa'nın Nutkundan da anlaşıldiğı üzere, kendisine bu malumat başkaları tarafindan verilmiştir. Hakikat nedir bilmiyorum. Bilmeme de imkân yoktur. Fakat benim katiyetle söyliceğim şudur ki, ben Yeşil Ordunun hiçbir safhası ile katiyen alakadar olmadım. Ağabeylerimden Tevfik Bey'in de hiçbir siyasi hareketin içinde olduğu söylenemez... Reşit Bey'in mizacı olarak mektum ve menfi faaliyet isteyen cemiyetlerin içinde bulunacağını

\footnotetext{
${ }^{37}$ Ethem, Hatıralar, s. 164.
} 
tahmin edemem. Çünkü kendisine sir verebilmenin kolay olmadiğını, daha Trablusgarp'tan itibaren dostu olan ve kadimen yakın arkadaşı bulunan Mustafa Kemal Paşa'nın da bilmesi icap ederdi... Ben şahsım ve kuvvetlerim namina katiyetle diyeceğim ki, resmi, hususi, aşikâr, gizli bir teşkilat ve cemiyete dâhil olmadım ve olmadlk. ${ }^{, 38}$

Çerkes Ethem'in Yeşil Ordu Cemiyeti ile ilişkisine dair bir ipucu da; Yeşil Ordu Genel Kâtipliğini yapmış olan Tokat Mebusu Nazım Bey hadisesinde bulunmaktadır. Nutuk'ta böyle bir açık ilişkiden bahsedilmemekle birlikte; 4 Eylül 1920 tarihinde meclis tarafindan Dâhiliye Vekâletine seçilen Nazım Bey'in; yabancılarla temas halinde bulunması, casusluk yaptığına dair belirgin faaliyetlerinin olması ve esasta Bolşevik propagandas1 yapmas1 gibi nedenlerle, Mustafa Kemal Paşa tarafindan uygun nitelikte bir kişi olmadığının değerlendirildiği nutukta yer almaktadır. ${ }^{39}$ Ethem ise hatıralarında, Nazım Bey'in, kendisinin (Ethem'in) Hacı Şükrü Bey ile yollamış olduğu mesajı üzerine istifa ettiğini açıklamaktadır. $^{40}$ Hacı Şükrü Bey ve Nazım Bey daha sonra İstiklal Mahkemesinde, Yeşil Ordu Cemiyeti ve diğer komünist faaliyetlerle ilişkileri nedeniyle yargılanmış ve suçlu bulunmuşlardır. ${ }^{41}$

Çerkes Ethem, Yeşil Ordu ilişkisinin önemli bir ayrıntısı da; Seyyare-i Yeni Dünya Gazetesinin yayınlanması safhalarında göze çarpmaktadır. Yeşil Ordu Genel Merkezine bağlı olarak faaliyet gösteren Eskişehir Şubesi kurucularından olan Mustafa Nuri, Arkadaş adlı bir gazete çıkarmaya başlar. Daha sonra Demirci cephesinden Eskişehir'e dönen Arif Oruç ${ }^{42}$, Ethem tarafindan 1920 Ağustos ayında aynı matbaada "Seyyare-i Yeni Dünya Gazetesi'ni çıkarmakla görevlendirilir. Matbaa o dönem için Anadolu' da en modern sistemlere sahiptir. Söz konusu gazete, Büyük Millet Meclisine karş1 Çerkes Ethem'in liderliğini ve Bolşevikliği savunmakta, başlığı altında; "Dünyanın Fukara-i Kasibesi(emekçileri) Birleşiniz" hitabı bulunmaktadır. ${ }^{43}$

${ }^{38}$ Kutay, Çerkes Ethem Tamamlanmış Dosya, s. 181.

${ }^{39}$ Nutuk, Türk Tarih Kurumu Yayınlar, Cilt II, Ankara, 2010, s. 670-672.

${ }^{40}$ Ethem, Hatıralar, s. 102-106.

${ }^{41}$ Fethi Tevetoğlu, Türkiye'de Sosyalist ve Komünist Faaliyetler, Ayyıldız Matbaası, Ankara, 1967, s. 180.

${ }^{42}$ Y1lmaz, Milli Mücadelede Yeşil Ordu, s. 114, d.n. 113, "Maceraperest ruhlu sosyalist bir gazeteci"; Tevetoğlu, A.g.e., s.180. "Arif Oruç; İstiklal Mahkemesi kararıyla, suçlu bulunmuştur."

${ }^{43}$ Hifzı Topuz, II.Mahmut'tan Holdinglere Türk Basın Tarihi, Remzi Kitabevi, İstanbul, 2003, s. 134-137. 
Seyyare-i Yeni Dünya Gazetesi, önce kendini “Türk Bolşevik”, sonra da "İslam Bolşevik" olarak tanıtmaktadır. Ethem gazetede yayınlanan bir mülakatta; "Milli Kahramanlarımızla Mülakat" başlığı altında şunları söylemektedir: "Iyi uygulanmak şartiyla, bu memleket ve bu milletin Bolşevikliği kabul etmekten başka çaresi kalmamıştır.” Bolşevikliğin cihanı istila edeceğine zat-1 aliniz kani bulunuyor musunuz? Sorusuna ise şu şekilde cevap vermiştir; "Evet, Bolşevizm cihan istila edecektir. Biz onu layık olduğu gibi bir hisle karşılayıp kabul edersek memleket bu durumda mesut olacaktır. "44 Ethem hatıralarında gazetenin mesleğinin sosyal demokrat olduğunu, vazifesinin ihtilal halinde ve istila tehlikesi içinde bulunan Türkiye'deki kardeş vatandaşları, Kuvayı Milliye ve B.M.M. etrafında toplamaya çalışmak, milli birliği temin etmek, ihtilalci hükümete de adalet ve hürriyet esasları dâhilinde hareket etmenin lüzumunu ihtar etmek olarak belirtmektedir. ${ }^{45}$

Ethem'in daha önce mülakat esnasında söyledikleri ile hatıralarında belirttiği hususlar tamamen birbiriyle çelişmektedir. Bu çelişkiden Ethem'in duygu, düşünce, tutum ve davranışlarındaki dengesiz yapıyı anlamak mümkündür.

\section{Çerkes Ethem'in Yozgat İsyanını Bastırmak Üzere Ankara'ya Çağrılışı ve Yaşanan Gelişmeler:}

Çapanoğulları tarafindan Yozgat bölgesinde çıkarılan isyanlar, Sivas tarafina, kuzeyde Tokat bölgesine doğru yayılmaya başlamıştır. İsyan bölgesi gittikçe gelişme göstermektedir. İsyan bölgesine gönderilen birlikler başarı sağlayamamış, dağılmışlardır. Bu gelişmeler üzerine hükümet; kuvvetlerini Eskişehir üzerinden Salihli'ye göndermekte olan Çerkes Ethem'i Ankara'ya çağırmıştır. ${ }^{46}$ Ethem Ankara'nın ısrarlı davetleri üzerine, oraya gitmek zorunda kaldığını şu sözlerle aktarmaktadır:

“Ankara'da Erkan-ı Harbiye-i Umumiye Vekâleti ve BMM Hükümeti, bir Yozgat derdine düşmüş, sızlanıp duruyorlardı...Ne yazık ki, Ankara'ya gidip durumu ve Ankara'daki çaresizliğe eklenen maneviyatsılı̆̆ gördüğ̈̈m vakit, Ankara'nın değil bir mevzii isyanı, hatta kuvvetlice bir eşkıya çetesini dahi tenkil ve tedipten aciz bulunduğunu görmüş ve anlamıştım...Ankara'ya vardı̆̆ım zaman, başta Mustafa Kemal Paşa olmak üzere, mazhar olduğum karşılamalar ve orada kaldığım birkaç günlük müddet zarfinda gördügüm iltifatlar, denilebilir ki, haddinden kat kat üstündü. Bu iltifat ve nümayişler, bana hiçbir gurur vermiyordu.

\footnotetext{
${ }^{44}$ Topuz, a.g.e, s.134-135.

${ }^{45}$ Ethem, Hatıralar, s. 110.

${ }^{46}$ Türk İstiklal Harbi, VI. Cilt, İç Ayaklanmalar 1919-1921, Gnkur. Basımevi, Ankara, 1964, s. 97-100.
} 
Hatta bunlardan hicap duyuyordum...Ankara istasyonunda ve ayakta beni karşılayan zevatla el sikıştıktan sonra, Mustafa Kemal Paşa beni otomobile aldl ve doğruca Ziraat mektebine vardlk ve indik. Bu bina Erkan-ı Harbiye-i Umumiyenin ve Müdafaa-i Milliye Vekâletinin dairesi ittihaz olmuştu. Mustafa Kemal, Ismet ve Fevzi Paşalar da aynı binada çalışır ve geceleri de orada kalıyorlarmış. Nitekim ilk gece beni de orada allkoydular. "47

Ethem, Ankara'ya ilk gelişi ve edindiği izlenimleri bu sözlerle ifade ettikten sonra, o gece Yozgat isyanı üzerine yapılan görüşmeleri özetle şu şekilde anlatmaktadır: Toplantıya; Mustafa Kemal ve Fevzi Paşalar ile İsmet Bey, kardeşi Tevfik ve Reşit Beyler ve Ethem katılmıştır. İsmet Bey, Yozgat'ta yaşananları açıkladıktan sonra maneviyatı güçlü Kuvayı Seyyarenin bu isyanın rahatlıkla üstesinden gelebileceğini belirtmiştir. Eskişehir'den Salihli'ye yapılmakta olan sevkiyatın durdurulmasını söylemiştir. Bunun üzerine Ethem, Yozgat'a müdahale için gerekli tedbirleri aldırmış olduğunu açıklamış, aslında bu isyanı önemsiz gördügünü vurgulamıştır. İsmet Bey, daha sonra teferruatlı bir bilgi vermiştir. Ethem'e göre, toplantıya katılanlar onun durum hakkında neler söyleyeceğini meraklı gözlerle beklemektedir. Ethem'in bu ortamda söylediğini iddia ettiği sözler gerçekten ilgi çekicidir:

"Hayret ediyorum ki, Sivas'ta Heyet-i Temsiliye ve Ankara'da Büyük Millet Meclisi sıfattyla içtima ve teşsekkül olunalı bir seneyi geçtiği halde, bu müddet zarfinda koca Anadolu'da, harekât-ı milliyemiz namına neden esaslı bir hareket görülmedi? Niçin merkezinizi takviye etmediniz? Ve sonra en mühim ve esas olan cephelere ait şimdiye kadar bir himmet ve muavenet eserinize dahi şahit olmadik desem itiraf buyrulur zannederim. Nihayet bizleri düşman cephesinden gerilere ayrlmă̆a ve surf gerilerde size düşen vazifelerle bizi işgale mecbur bıraktınız!"

$\mathrm{Bu}$ ifadelerden sonra; sözlerine şöyle devam eder:

"Şimdi görüyor ve siz de itiraf buyuruyorsunuz ki, Orta Anadolu'da ve bir köşede hiçbir ecnebi ile ve Istanbul hükümeti ile irtibatı kalmayan Yozgat isyanını söndürmekten acizsiniz. Anladı̆̆ım şudur ki, bidayetten beri hala vaziyeti kavrayamadınız. Veyahut şahsi ve daha ehemmiyetsiz şeylerle meşgul oluyorsunuz. Ve belki de Heyet-i Temsiliye ve Ankara Hükümeti namına yaptığınız tamimlerle, tebliğlerle, konferanslarla her şey olup bitiverecek sandınız ve aldandınız. Af buyurunuz, bu serzenişten muradım, bu gafletler tekerrür etmesin

\footnotetext{
${ }^{47}$ Ethem, Hatıralar, s. 52-53.
} 
temenniyatına mebnidir. Ben bu kalan isyan meselesini de uhdeme alıyorum. Ve sizleri bu gaileden kurtaracağımı ümit ediyorum." 48

Daha sonra adeta emir verir gibi; "Lakin ben bu vazifeyi ifa edip dönünceye kadar Yunan cephesinin mesuliyetini, üçünüzden biriniz kabul buyurmalısinız. Şu şartla ki, Salihli'de bulunmak ve Cephe Kumandanı Ali Fuat Paşa'ya tabi olmak üzere..." demiştir. Ethem'in hatıralarına göre bu şart da dinlenmiş, Fevzi Paşa'nın cepheye gitmesi kararlaştırılmıştır. Tüm faaliyetler karara bağlanınca Mustafa Kemal Paşa'nın şunları söylediğini belirtmektedir:

"Yozgat havalisindeki isyanin mahiyeti ve ehemmiyeti ne olursa olsun himmetinize arz-l iftikar eyliyor demektir. Bu zahmeti de deruhte buyurduğunuza nazaran, bermutat beş on gün zarfinda bastıracağınıza eminim... Bu tip hareketinizin devamı müddetince, İmir Milli Cephemizin nezaret ve teftişi vazifesini Fevzi Paşa Hazretlerinin uhde-i liyakatına vermemiz ve lütfen bunu üzerine almalar pek muvafik olur kanaatindeyim. Fevzi Paşa Hazretlerinin zekâ ve iktidarından nüfuz-u nazar ve liyakatlerinden zat-ı alileri de emin olabilirsiniz. "49

Tüm bunlara ilave olarak Ethem hatıralarında, Mustafa Kemal Paşa'nın kendisine şu sözlerle hak verdiğini de açıklamaktadır:

"Evet, cereyan eden hal ve maziye ait ataletimizi hedef tutan şikâyetlerinizde hakkınız yok değildir. Çünkü kendileriyle iş görmeye çalıştı̆̆ımız arkadaşlar ve Millet Meclisi azalarının ekseriyetle ne dereceye kadar tereddütkâr, müşkülpesent hatta bir kısmının fesatlar içinde olduğuna vakıf değilsiniz. Millet Meclisi azaları arasında kalben Istanbul Hükümetine taraftar ve menfi bir siyaset takip eden halifeye bağll kimseler vardır. Vatansız ve istiklalsiz hilafet makaminın manasızlığını idrakten aciz kimseler, eski ve alelade zamanlara ait kanunlar haricinde hareket edilmemelidir, diyorlar. Hatta çoktan beri zaruri gördüğ̈̈müz Hiyanet-i Vataniye Kanununu tasdik ettirinceye kadar göbeğimiz çatladı... Karşı tarafta bütün mevcudiyetiyle ve her vasita ile meşru müdafaamız içerden ve dışardan felce uğratmak için en şen-i hareketlerle, şimdiye kadar az çok teşkil ettiğimiz kuvvetleri dağıttılar. Sizin kuvvetlerinizi cepheden ayırmağa mecbur kaldık.", 50

Ethem'in anlattı̆̆ına göre; bu toplantıyı müteakip; odada Mustafa Kemal Paşa ile yalnız kalırlar. Bir ara odaya Halide Edip Hanım gelir, ona beslediği hürmet, tanıştıktan sonra bir kat daha artar. ${ }^{51} \mathrm{Bu}$ arada meclisten

${ }^{48}$ Ethem, Hatıralar, s. 55-57.

${ }^{49}$ Ethem, Hatıralar, s. 56-57.

${ }^{50}$ Ethem, Hatıralar, s. 57-58.

${ }^{51}$ Ethem, Hatıralar, s. 59-60. 
gelen bir heyet, kendisini meclise davet eder, meclise geldiğinde bir alkış tufanının koptuğunu, kendisine gösterilen aşırı ilgi ve tezahürattan utandığını, meclis görüşmelerini bir müddet izlediğini, meclisin memleket meselelerine hâkim olduğunu görmekten mutluluk duyduğunu belirtmektedir. $^{52}$

Ethem, Ankara'da bulunduğu sürede Taş Han'da, Diyarbakır Mebusu Hacı Şükrü Bey'in yanında, geceleri de meclis binasında kendisine tahsis edilen odada kalmıştır. Meclis azalarıyla yaptığı görüşmelerde, çoğunun Mustafa Kemal'den şikâyetçi olduğunu, yapılan dedikoduların Ankara'da yaşanan maneviyatsızlıktan kaynaklandığını hatıralarında belirtmektedir. Bu arada bazı samimi gaye arkadaşları edindiğini, bunların müsait bir zamanı kolladıklarını, ayrıca Ankara'yı adeta bir sığınak olarak değerlendirdiğini de eklemektedir. ${ }^{53}$

Ethem'in anlatmış olduğu bu hikâyelerin doğruluk derecesini, aktardığı sahneler ve Milli Mücadele'nin en üst düzey liderlerinin tutumları hakkında söylediklerini net olarak kanıtlamak mümkün değildir. Ancak, Nutuk'ta satır aralarında belirtildiği gibi; Ethem'in Ankara'da bulunduğu sürede bazılarının abartılı iyi niyet gösterilerinde bulunması, o dönem için Ethem kuvvetlerine olan ihtiyaç, gibi hususlar göz önünde tutulduğunda gerçeklik payının çok da az olmadığını değerlendirmek mümkündür.

\section{Yozgat İsyanının Bastırılması ve Sonrasında Yaşananlar:}

Çerkes Ethem'e Yozgat'ta yaşanan isyanın bastırılması amacıyla, 19 Haziran 1920 tarihinde, Erkan-1 Harbiye-i Umumiye Reisi İsmet Bey tarafindan, teferruatlı bir istihbaratı da içeren harekât emri verildi. ${ }^{54}$ Ethem almış olduğu bu harekât emrine tepkisini hatıralarında özetle şu şekilde dile getirmekte, askeri ve milli kumandanları makam ve rütbelerini dikkate almaksızın aşağılamaktadır:

"Erkan-ı Harbiye-i Umumiyesin isyan bölgesi hakkındaki resmi tebligatı, yanlış istihbarata ve eksik bilgiye dayanmuştır. Bazı bölgelerde olduğu belirtilen Kuvayı Milliye birlikleri ve adı geçen komutanlar kendilerini güvenli bölgelere çekmiş ve hatta dağılmışlardır... Kılıç Ali Bey kumandasindaki piyade ve süvari birlikleri, zaylf bir asi topluluğu tarafindan tamamen dağıttlmıştır... Miralay Refet Bey, üç yüz kişilik milli ve zeybek müfrezesiyle, Çorum'un içine gizlenmişs ve bize hiçbir yardımları olmamıştır... Sadece Zile ve Tokat civarında Cemil Cahit Beyin yararlılıkları görülmüsstür... Sonuç olarak bize verilen istihbaratı

\footnotetext{
${ }^{52}$ Kutay, Çerkes Ethem Tamamlanmış Dosya, s. 176-180.

${ }^{53}$ Ethem, Hatıralar, s. 61.

${ }^{54}$ Türk İstiklal Harbi, VI. Cilt, İç Ayaklanmalar 1919-1921, s. 100-102.
} 
ihtiyatl bir şekilde yorumlayıp, yardim etmesi gerekenleri yok saylp, tecrübelerimize ve kendi istihbaratımıza dayanarak isyan bölgesine girilmiştir. ${ }^{\text {"55 }}$

Ethem hatıralarında, Yozgat isyanının bastırılması öncesi durumu bu şekilde aktarmak suretiyle, Büyük Millet Meclisi Hükümeti ve bunun komuta kademesine karşı beslediği güvensizliği ortaya koymaktadır. Bunun yanında her şeyi kendi kurallarına göre uygulamakla başarıya ulaştığını, dolayısıyla kendi Kuvayı Seyyaresinin ancak bu şekilde yönetilmekle kullanılabileceğini yansıtmaktadır.

Sonuçta, Yozgat isyanı Haziran 1920 sonlarında kanlı ve başarılı bir şekilde bastırılmıştır. Çerkes Ethem, bu harekât sonrası almış olduğu telgraf suretine de hatıralarında yer vermiştir.

"Alaca Havalisinde Kuvayı Tedibiyye Umum Kumandanı Ethem Beyefendiye, 28 Haziran 1920; Son Arap Seyfi Boğazında vaki muvaffakiyet-ı kahirinizden dolayl ansamim-ül-kalb zat-ı alilerini ve rüfekayı besaletinizi tebrik eyleriz. Münhezimden dağılan perakende asilerin mintıkalarında takipleri için Çorum'da Refet Beye, Zile'de Cemil Cahit Beye buradan da emir verildiği maruzdur efendim. B.M.M. Reisi Mustafa Kemal ${ }^{, 56}$

Ethem Yozgat isyanının bastırılması sonrası kendiliğinden bir de beyanname kaleme alarak bütün Anadolu'ya yayınlamıştır. ${ }^{57}$ Yozgat isyanı sonrası yaşanan en önemli gelişme, Ethem'in bölgedeki işlerini bitirip, Yozgat'a dönmesiyle başlar. Özellikle Ankara Valisi Yahya Galip Bey hakkındaki gelişmeler, Ethem'in hatıralarında geniş yer almaktadır.

Yozgat'ta Ethem Bey'in kardeşi Tevfik Bey'in başında bulunduğu harp divanı sorgulamaları esnasında, Yozgat Mutasarrıfını suçlu bulur. Ancak, asıl suç, yapılan şikâyetlere rağmen bu şahsı vaktinde değiştirmeyen Ankara Valisi Yahya Galip Bey'de görülür. Hatta Mustafa Kemal Paşa da dolaylı olarak bu durumdan suçlu bulunmaktadır. Dolayısıyla Yahya Galip Beyin suçu işlediği yer olan Yozgat'ta sorguya çekilmesi kararı verilir. Bu durum divan-1 harp tarafindan Çerkes Ethem'e iletilir ve derhal Yahya Galip Beyin Ankara'dan getirtilmesi istenir. Bu durum çerçevesinde Ethem ile Ankara Hükümeti arasında telgraf yazışmaları olmuş, nihayetinde valinin işten el çektirildiği, kendisinin hasta olması nedeniyle Yozgat'a yollanamayacağ Meclis Başkanı Mustafa Kemal Paşa tarafından, Ethem'e bildirilmiştir.

${ }^{55}$ Ethem, Hatıralar, s. 64-65.

${ }^{56}$ Ethem, Haturalar, s. 71.

${ }^{57}$ Ethem, Hatıralar, s. 71-72. 
Ethem hatıralarında bu durumu şu şekilde yorumlamaktadır:

"Hususi telgraf ve muhaberelerden çıkardığımı manaya ve sonradan tahakkuk ettiğine göre Mustafa Kemal Paşa'nın bütün telaşına sebep; Yahya Galip Beyi ve mevkuf Yozgat Mutasarrıfinı korumaktan ziyade, Yahya Galip Beyin ifadesine müracaat edecek olan salahiyettar ve adil bir divan-l harp heyetinin sonradan kendisini de (Mustafa Kemal Paşa'yı da) sorgu altına alacă̆ını bildiği ve bütün mesuliyetin kendisine terettüp ve teveccüh edeceğinden korktuğu anlaşılmışt. Esasen bu hususlara vaklf olan ve Yozgat'ta bulunan bazı kimseler Divan-ı Harp Heyetini en ince teferruatına kadar aydınlatmışlardı."

Ethem, bu düşüncelerini de belirttikten sonra; kardeşi Mebus Reşit Beyin de araya girmesiyle Yahya Galip Bey olayını kapattı̆̆ını açıklamaktadır. ${ }^{58}$

\section{Kuvayı Seyyare'nin Demirci Harekâtı:}

1920 Haziran ay1 sonuna kadar hareketsiz durumda bulunan Garp Cephesinde, Yunan ileri harekâtı başlamıştır. Yunan birlikleri tarafindan Nazilli, Alaşehir, 30 Haziran'da Balıkesir ve nihayet 2 Temmuz'da Bursa işgal edilmiştir. 29 Ağustos’ta da Uşak ele geçirilmiştir. ${ }^{59}$

Ethem'in hatıralarına, bu dönem için göz attığımızda; gizli ve acele şifreli telgraflar almaya başladığını, bunlardan en detaylısının aşağıdaki şekilde olduğunu beyan etmektedir:

"Yozgat'ta Kuvayı Tedibiye Umum Kumandanı Ethem Beyefendiye, 3 Tеттиz 336;

Yunan ordusunun ani taarruzu neticesi, cephelerimizi bozmaya muvaffak olarak ileri harekete geçtiğini, bundan evvelki şifreli telgrafla bildirmiştim. Erkan-l Harbiye-i Umumiyeye gelen son harp raporlarına göre, hiç bir tarafta ciddi mukavemet gösteremeyen nizami ve milis kıtalarımız düşman ilerledikçe erimekte ve dă̆lmakta, müdafaayı zayıf bulan düşman ordusu da iki koldan ileri harekâtına devam etmektedir. Bir kolu Balıkesir'i, diğer kolu Alaşehir ve civarını işgal etmiş bulunuyor. Ĕger Yunanlılara herhangi bir taraftan bir darbe indirmeye muvaffak olamazsak durmadan ilerleyecekler. Kuvayı Milliye'nin can damarların teşkil eden mühim noktalarl ellerine geçireceklerdir. Bu pek tabiidir. Bundan çıkacak fenalığın ve tehlikenin önünü almak şu vaziyet içinde bizler için sonradan mümkün olamayacaktır. Henüz yeni ortadan kaldırılmış tehlikeler şüphesiz yeniden canlanacaktır.

Böyle bir mukavemeti, böyle bir vazifeyi üzerine alıp başarabilecek olan kuvvet, ancak sizin maneviyatı kırllmamış müfrezelerinizdir. Bu

\footnotetext{
${ }^{58}$ Ethem, Hatıralar, s. 72-78.

${ }^{59}$ Türk İstiklal Harbi, II. Cilt, Batı Cephesi, 2. Kısım., Gnkur. Basımevi, Ankara, 1966.
} 
itibarla tedipleri sona eren Yozgat havalisinin asayişine geri kalan ufak tefek meselelerle meşgul olmak üzere Miralay Çolak İbrahim Beye Ankara'dan Yozgat'a hareket etmesi emrini şimdi verdim. Erkan-l Harbiye-i Umumiye Reisi Miralay İsmet. ${ }^{" 60}$

Bu mesaj1 alan Çerkes Ethem, önce Yozgat'tan Ankara'ya, oradan da Garp Cephesi kumandanı Ali Fuat Paşa ile buluşmak üzere İnönü'ye gider. Burada Ali Fuat Paşa'nın durum değerlendirmesini dinler. İnönü'de toplanan harp meclisi kararlarına göre, Ethem birliklerinin Kütahya-Simav-Demirci istikametinde hareketi ve bu hatta Kuvayı Seyyare tarafindan bir müdafaa oluşturulması kararlaştırılır. Ethem birliklerinin harekâtı sonucu Demirci ve civarı tamamen düşmandan geri alınır. Burada Mustafa Kemal Paşa'dan bir telgraf alır:

"Demirci Havalisinde Ethem Beyefendiye, Afyonkarahisar, 13 Temmuz 336 (Mühim ve Mahrem)

Daima gözü ileride olan mütearrız düşman kıtalarının kesafeti nispetinde buralarda kuvvet bulamadım. Elden geldiği kadar takviye ettirdiğim Aşir Bey firkasl son bir gayretle Uşak önünde müdafaa halindedir. Bütün nazarlar ve ümit tecrübe görmüs müfrezelerinizin atıllşları neticesine çevrilmiştir. İstenen topçu mühimmatı size süratle ulaştırılmak üzere yola çıkarılmıștır. Afyon'da B.M.M. Reisi Mustafa Kemal"'

Demirci bölgesinde, bir müdafaa hattı tesis edilmesi esnasında almış olduğu telgraf ise şu şekildedir:

"Demirci Havalisinde Ethem Beyefendiye; Afyon, 14 Temmuz 336, Müstacel;

Demirciyi geri alan kahraman müfrezelerinizin mütemadi kahramanca hücumlarlyla bozulan ve askeri vaziyetini islah derdine düssen Yunan ordusunun ileri hareketi durduğu ve gevşediği, cephelerden gelen son raporlardan anlaşlllyor. Sol kanadinizl tehdit eden yeni düssman kuvvetinin bu cephede geri alındı̆̆ ve Kula yoluyla üzerinize gönderildiğini haber aldık. Yardımınıza bir askeri kıtanın gönderilmesini Uşak civarındaki firka kumandanına emrettim. Benim Ankara'ya dönmekliğim mecburiyeti hâsıl oldu. Sebebinin izahı, şifre ile dahi caiz değildir. Bu hususta şifahi bilgi vermek üzere Tevfik Rüştü ve Hüsrev Sami Beyler şimdi hareket ettiler. Gözlerinizden öper, başarılarınızı tebrik ederim. Mustafa Kemal ${ }^{\text {,61 }}$

Ancak Ethem birlikleri kazandıkları başarıyı sürdürememiş, Yunan kuvvetleri ise sürekli takviye edilmiştir. Ethem, kuvvetlerini düzenli olarak belirli bir hatta çekmeye çalıştığını, ancak Fahrettin Bey ve Aşir Bey kuvvetlerinin düşman baskısına dayanamadığını, bu nedenle cephede

\footnotetext{
${ }^{60}$ Ethem, Hatıralar, s. 78-79.

${ }^{61}$ Ethem, Hatıralar, s. 80-92.
} 
başarısızlığın nizami kuvvetlerden kaynaklandığını ifade etmektedir. $\mathrm{Bu}$ dönemde önceki rahatsızlı̆̆ının yeniden nüksettiğini, önce Kütahya'da tedavi gördüğünü, sonra da Eskişehir'e de uğrayarak Ankara'ya gittiğini belirtmektedir. ${ }^{62}$ Ankara'ya geldiğinde ilk olarak karşılaştığı mesele, Dâhiliye Vekâletine seçilen Nazım Bey hakkındadır. Bu konuya Ethem'in Yeşil Ordu ile ilişkisi ve Bolşevizm hakkındaki düşüncelerinin incelendiği bölümde yer verilmiştir. ${ }^{63}$

\section{Çerkes Ethem'in Hatıralarında Gediz Taarruzu (24 Ekim 1920)}

Ethem'e göre; Gediz bölgesinde kendi birliklerinden ayrı, müstakil bir durumda kalmış bulunan Yunan fırkasına taarruz, ordu emrinde ve ihtiyatında teşkilatını yeni tamamlamış olan nizami fırkalar için iyi bir tecrübe olacaktır. Ali Fuat Paşa da Ethem'in yapmış olduğu bu teklifi uygun görür. Ali Fuat Paşa'nın yeni teşkil edilen 8 nci ve 11 nci piyade firkalarına itimadı tamdır ve bu birlikler ordu emrinde hazır bulunmaktadır. Gediz'de ayrı bir halde bulunan bir firkalık Yunan kuvvetine yapılacak kesin bir baskın şeklindeki taarruzun iyi netice vereceğine inanmaktadır. Ancak Erkan-1 Harbiye-i Umumiye, bu arzusuna muhalefet etmektedir. Bu harekâtın nasıl yapılacağ1 hususunda Alayund İstasyonunda firka kumandanları huzurunda toplanacak bir harp meclisinde konunun ve taarruz zamanının tartışılmasına karar verir. Ethem'i de bu toplantıya katılmak üzere çağırır.

Neticede, Alayund'da toplantı yapılır ve taarruz kararı alınır. Ancak bu sırada, Konya'da baş gösteren bir isyanı bastırmak üzere Refet Bey emrine 300 kişilik bir Kuvayı Seyyare müfrezesi göndermenin zorunluluğu ortaya çıkar. Taarruza bu müfrezenin dönüşü beklenmeden başlanır, ancak istenen sonuç elde edilemez. Ethem, aslında kendi birliklerinin üzerine düşen görevi layıkıyla yaptığını ve Kuvayı Seyyarenin bu taarruzda başarılı olduğunu belirtmektedir. Ancak Ethem'e göre; nizami birlikler düşman önünde yetersiz kalmış ve onlar yüzünden harekât başarısızlığa uğramıştır. ${ }^{64}$

Ethem, Gediz taarruzundan sonra olayların kendi aleyhine gelişmiş olduğuna hatıralarında geniş bir şekilde yer vermektedir. Ethem'e göre; Ali Fuat Paşa'nın yerine Garp Cephesi Kumandanlığına İsmet Paşa'nın, Cenup Cephesi Kumandanlığına Refet Bey'in gelişinin sebebi; Ethem ve kuvvetleri aleyhine Mustafa Kemal Paşa'da mevcut olan düşünceye vakıf olmalarıdır. Onlar Gediz taarruzunun başarısızlıkla sonuçlanmasından sonra, Mustafa Kemal Paşa'nın düşüncesini gerçekleştirmek için en elverişli zamanın

${ }^{62}$ Ethem, Haturalar, s. 92-102.

${ }^{63}$ Ethem, Hatıralar, s. 102-110.

${ }^{64}$ Ethem, Hatıralar, s. 110-121. 
geldiğini anlamışlardır. Ali Fuat Paşa'da ise böyle bir plana iştirak kabiliyeti görülmemiştir. İsmet Bey ve Refet Bey, bundan sonra Kuvayı Milliye namına iç ve dış kamuoyunda çok elverişli durumların yaşanacağını görmüşlerdir. Onlara göre, Ethem ve etrafı genel kamuoyunda kazandığ 1 mevkii ve itimat sayesinde kendilerinin her teşebbüsüne engel teşkil edecektir. $^{65}$

\section{Düzenli Orduya Geçiş Süreci}

Ethem, kendisine yöneltilen isnatlardan birinin de; "Ethem serkeş, emir dinlemez, danışma kabul etmezdi. Nizami asker teşkilatına muhalefet eder, ordunun kuvvetlenmesine karşı gelir" olduğunu belirtmektedir. Ancak bunun doğru olmadığını, kendisi ve çevresinin işin başından beri ordu ve nizami teşkilatı temsil eden Kıta'ları, zorluklar karşısında dağılınca topladığını, millet arasında birliği sağlamaya vasıta olduğunu, orduya şerefini kazanma fırsatları sağladığını belirtmektedir. ${ }^{66}$ Ethem, cephe kumandanlarının değiştirilmesi gerekçesinin, bundan sonra yapılmaya başlayan uygulamalarda ortaya çıtı̆̆ını; Kuvayı Seyyare ve Ethem aleyhinde yapılan propagandanın ordu içinde yayılmaya başladığını; birkaç gün öncesine kadar milli kahraman diye alkışlayanların ve hala da yüzüne karşı gülenlerin ve okşayanların, kendisine karşı emrivakiler yaratmaya çalıştıklarını; elde ettiği haberlerden de bunların doğrulandığını belirtmektedir. ${ }^{67}$

Ethem kendisi aleyhinde yapılan propagandanın ana çerçevesini şu satırlarda belirlemekte, Nutuk'ta ve genelde kendisine yöneltilmiș olan isnatları sıralamaktadır. Bunu uygulama alanına koyan kişinin de Garp Cephesi Baş Baytarı Galip Bey olduğunu açıklamaktadır:

“Kuvayı Seyyare Kumandanı Ethem Bey, hastalı̆̆nı bahane ederek, cephenin işlerini biraderi Tevfik Beye birakarak gerilerde başka işlerle uğraştı̆̆ anlaşllyor. Evet, asla rahat duruyor sanmayınız. Ethem Bey sözde tedavide. Hâlbuki hiç durmadan merkez ve şehirlerde mahiyeti belirsiz bir takım hususi teşkilatla gizli ve açık çalışmaktadır. Millet ve Meclis nezdinde her istediğini yaptırabilecek bir nüfuza sahip! Ali Fuat Paşa'nın müsamahalı taraftarlı̆̆ kendisini lüzumundan fazla şımarttı. Evet, zaman ve hadiseler bunun sivrilmesine yardim etti. Ethem Beyin hizmetleri inkâr edilemez. Lakin acaba maksadl vatanperverane ve sadıkane midir? Son tutumları düşünülmeye değer, Miralay İsmet Beyin kumandanlığına itiraz ediyor. Refet Beyi hiç istemiyor. Çünkü bunlar Ali Fuat Paşa gibi Ethem Beyin tesiri altına girmeyecek ve istediği gibi oyun

\footnotetext{
${ }^{65}$ Ethem, Hatıralar, s. 121-122.

${ }^{66}$ Ethem, Hatıralar, s. 122.

${ }^{67}$ Ethem, Hatıralar, s. 123.
} 
oynamasına meydan vermeyecekler. Kardeşi Tevfik Bey ise küstah, geçen gün telefonla cepheden emir vermiş, Kütahya Merkez Kumandanı vasitasiyla Kütahya Mutasarrıf Vekilini evinden hakaretle aldırıp, şehirden tard ettirmiştir. Bunun kabahati güya asker kaçakların koruyormuş. Hatta takipleri hususunda müsamahalı davranıyormuş.

Ankara Hükümeti bu mutasarrıf vekilini vazifesine geri göndermek isteyince Tevfik Bey telgrafla Ankara'ya şu cevabı vermiş; bu fesatçıy geri gönderirseniz asarım.

Kuvayı Seyyare zabit ve efrad, nizami kltalar kumandan ve askerleriyle kıyas edilemeyecek kadar fazla maaş altyorlar. Bütün müdafaa-i milliye cemiyetleri Ethem'in nüfuzu altında, istediği parayı derhal gönderiyorlar.

Kuvayı Seyyarede Çerkesler çoğalıyor. Çerkes zabit ve efradına daha fazla imtiyaz veriyor. Bunların nazarında başkaları sıfırdır. Hâlbuki Kuvayı Seyyare namı altında bidayetten beri şimdiye kadar Ethem Beyin emrinde ölen, kan döken ekseriyetle Türkler değil mi? Böyle olduğu halde nam, şöhret ve şeref başkalarının ",68

Ethem, aleyhinde artan yoğun propaganda karşısında, kardeşi Mebus Reşit Beye şu hususları aktarır:

"Ordu arasinda hususi vazifeliler vasitastyla, aleyhimizde fesatçı propagandalar açıkça ve vefasızca devam ediyor. Gün geçtikçe kalıcı olan bu durumun onarlamayacak bir safhaya gelmeden, B.M.M. 'de açık müzakereye götürünüz. Bu hususu size daha önce de söylemiştim. Anladım ki, siz hala kandırlabiliyorsunuz. Fakat iyi niyete dayanan bu ihmalinizin act neticeleri itibarlyla sonraları siz de pişman olacaksınız. Bilmeyerek alet oluyor, onlara firsat kazandırlyorsunuz. Ben her şeyden ziyade şuna teessüf ederim ki, Kuvayı Milliyemiz arasında çıkacak bir uygunsuzluk karşımızda bulunan Yunan ordusuna yeniden cesaret, ümit ve hayat verecektir. "69

Reşit Bey ise, Mecliste açık görüşmenin siyasi mahzurlar yaratacağını iddia eden samimi dostlarının olduğunu; yabancılara durumun yansıması halinde bundan fesatçıların yararlanacağını; Mustafa Kemal'den 1srarla icraat isteyeceğini; sabırlı olması gerektiğini belirtmiştir. ${ }^{70}$

Ethem'e göre; Dâhiliye Vekili Refet Bey, iki buçuk aydır Konya havalisinde kendisine karşı kuvvet toplamaktadır. Emrindeki Fahrettin Bey

\footnotetext{
${ }^{68}$ Ethem, Hatıralar, s. 123-125.

${ }^{69}$ Ethem, Hatıralar, s. 125.

${ }^{70}$ Ethem, Hatıralar, s. 125-126.
} 
vasıtasıyla Türklük-Çerkeslik cereyanı yaratmaya çalışmaktadır. Refet Bey, Ethem Yozgat'tan ayrılırken, halka karşı aleyhinde tehditler savurmuştur. $\mathrm{Bu}$ arada Ethem' in asilerden kendilerini affedip ellerine vesika verdiği kişileri toplamış, bunların ellerindeki vesikaları almış, Ethem'in böyle bir yetkisi olmadığına dair tehditler savurmuştur. Gene aynı bölgede Alevi Ruhani Reisi Dede Galip'in çalışmalarını sekteye uğratarak, bölge halkının infialine neden olmuştur. (EK-1 Refet Bey'e Telgraf) Ethem, Refet Beyi bu yaptıklarından dolayı Eskişehir İstiklal Mahkemesine bildirmiş ve durumdan Meclis Riyasetini haberdar etmiştir. Mahkeme, Meclis Riyasetine bir tezkere yollayarak Refet Beyi ifade vermek üzere çağırmıştır. Ancak Mustafa Kemal Paşa ve İsmet Beyin araya girmesiyle olay kapanmıştır. ${ }^{71}$

Ethem yaşanan bu olumsuz gelişmeler üzerine, İsmet Bey ile yüz yüze görüşmeye gider ve son günlerdeki gelişmeleri hiddetle anlatır. İsmet Bey ise, kendisinin de bu fesatçılardan bıktığını; Ethem'i Ali Fuat Paşa'dan bile çok sevdiğini belirtir. Ethem'e, Refet Bey evrakının mahkemeden geri aldırmasını, Refet Bey'in de Ethem'i çok takdir ettiğini söyler. İsmet Bey konuşmasına devamla; Ethem'e takdir edeceği bir rütbenin verilebileceğini de belirtince; Ethem, kendisinin rütbe meraklısı olmadığını, Refet Bey ile kişisel bir husumetinin olmadığını, Refet Bey’le ilgili faaliyetin tamamen İstiklal Mahkemesi takdiri ile sürdüğünü söyler ve Ankara'ya döner. ${ }^{72}$

\section{Gerilimin Tırmanması ve Ankara'da Yaşananlar:}

Ethem, gerilimin iyice tırmandığı zamanda son olarak Ankara'da yaşananları hatıralarında şu şekilde aktarmaktadır;

Meclis civarında ve içinde bazı azalar, Ethem lehinde bazıları ise aleyhinde dedikodular yapmaktadır. Bir kısmına göre de bütün kabahat kardeşi Tevfik Bey'e yüklenmektedir. Mustafa Kemal Paşa ile şahsen bir görüşme yapar. $\mathrm{Bu}$ görüşmede, Mustafa Kemal Paşa'nın Tevfik Beyin yaptıklarından son derece müteessir olduğunu ve kendisine; "Siz Kütahya'dan ayrildıktan sonra Garp Cephesi Kumandanı İsmet Bey ile Kuvayı Seyyare Kumandanı Tevfik Bey arasında anlaşmazlık artmıştır. Bu itibarla sizin acele Kütahya'ya dönmenizi rica ederim" dediğini ve bir telgraf gösterdiğini; telgrafta Tevfik Beyin imzası olduğunu ve İsmet Beye çekildiğini, şu hususları ihtiva ettiğini belirtmektedir:

“Gediz Kuvayı Seyyare Karargâhından, Eskişehir'de Garp Cephesi Kumandanı Ísmet Paşa 'ya; 20 Kânunuevvel 1336;

\footnotetext{
${ }^{71}$ Ethem, Hatıralar, s. 126-128.

${ }^{72}$ Ethem, Hatıralar, s. 128-134.
} 
Lüzumsuz ve bize haber vermeden Kuvayl Seyyare cephesi mıntıkasına gönderdiğiniz Kaymakam İbrahim Beyi, mahiyetindeki süvari müfrezesi ile beraber size gönderdim. Buna asıl sebep, Garp Ordusu Kumandanliğı namına birlikte getirdiği ve mintıkamız dâhilinde bazı yerlere astırdiğl görülen beyannameler olmuştur. Bu beyannamelerde Kuvayı Seyyareyi idare edenlerin itimada layık olmadı ğ bildirilmektedir. Fesat yaratan beyannameleri toplattım. Kuvay Seyyareye ve bize şerefsizlik isnat eden sizin gibi bir kumandan bundan sonra merci olarak tanımakta mazurum. Ve sizinle münasebetlerimi kestiğimi bildiriyorum. Kuvayı Seyyare Kumandan Vekili Tevfik" 73

Ethem, aynı gün bu mesele çerçevesinde kendisine de Tevfik Bey'den bir telgraf geldiğini; Bu telgrafta da Tevfik Bey'in, İsmet Paşa'nın haysiyet kırıcı davranışlarından bahsettiğini ve özetle şu hususları ihtiva ettiğini belirtmektedir;

"Ankara'da Kuvayı Seyyare Kumandanı Ethem Beye;

Aylardan beri cephemiz gerisinde ve cenahlarinda cereyan eden ve gittikçe müzminleşen münasebetsiz hale bir nihayet vermek için, Ankara'da ciddi ve resmi teşebbüslerde bulunmanızı rica ederim. Biz karşımızdaki düşmanla mı, yoksa arkamızdaki ve yanımızdaki kumanda mevkiine getirilenlerle mi ŭgraşacağız? Ben bu şartlar altında vekâleten üzerime aldı̆̆ım bu vazifeye devam etmekte mazurum. Ya durumu düzeltiniz yahut cepheye gelip vazifeyi üzerinize alınız. Bir cihetten Cenup Cephesi Kumandanlı̆̆ tarafindan kitalarımız arasina gönderilen propagandacılar, zabit ve efradımızı ifsada çalışıyor sonra savuşuyorlar. Fakat bundan sonra gelecek ve ele geçirilecek olan bu gibi fesatçıların yakalanarak karargâhıma gönderilmesini kumandanlarıma bildirdim. Mahkemesiz ve kayıtsız ve şartsı kendilerini idam ettireceğim. Kuvayı Seyyare Kumandan Vekili Tevfik"

Ethem hatıralarında bu telgrafı aldığının gecesi, Demirci Mehmet Efe'nin de kendisini telgraf başına çağırarak; Konya'ya Refet Bey tarafından çağrılmasıyla ilgili akıl danıştığını beyan etmektedir. ${ }^{74}$

\section{Çerkes Ethem ve Kardeşlerinin İkaz Edilmesi}

Ethem hatıralarında; Tevfik Bey ile İsmet Bey arasında yaşanan olayların giderilmesi amacıyla, Kütahya'ya döndüğünü; ancak üç gün sonra Mustafa Kemal Paşa'dan bir telgraf aldığını; 25 Aralık 336 tarihli telgrafta,

\footnotetext{
${ }^{73}$ Ethem, Hatıralar, s. 134-135.

${ }^{74}$ Ethem, Hatıralar, s. 135-137.
} 
İstanbul'dan Ankara'ya gelmek üzere yola çıkan Sadrazam Ahmet İzzet Paşa Heyetinin karşılanması için meclis azalarından bir heyet gönderileceğinin, heyet arasında Ethem ve kendisinin de bulunmasının uygun görüldüğünden bahsedildiğini; rahatsızlığına rağmen özel bir trenle Ankara'ya dönmesinin beklendiğini açıklamaktadır. Bu telgraf üzerine on beş kadar muhafızı ile birlikte, gönderilen özel trenle Ankara’ya gelmiştir. Mustafa Kemal Paşa ve Dr. Adnan Bey kendisini ziyaret etmiş ve yola çıkabilmesi için Mustafa Kemal Paşa Adnan Beye talimat vermiştir. Ethem bu ziyaret esnasında Mustafa Kemal Paşa'nın davranışlarında bir gariplik hissettiğinden de bahsetmektedir.

Heyetle birlikte Eskişehir'e ulaştıklarında, kendi beyanına göre Ethem, buradaki karargâh odasında dinlenmek için trenden ayrılır. Burada kendisiyle özel olarak iki subayın görüştüğünü; bunların Garp Cephesi Kumandanı İsmet Paşa'nın iki gündür Bilecik civarında faaliyet halinde olduğunu ve kendisine yönelik bir suikast hazırlığının Eskişehir veya Bilecik'te tertiplendiği şeklinde ifade de bulunduklarını; bu bilgiyi aldıktan sonra işi şansa bırakmak istemediğini; bu amaçla Mustafa Kemal Paşa ve yanındakileri kontrol altında tutmak üzere istasyonda gerekli tedbirleri aldırdığını belirtmektedir. Eskişehir'de odasında istirahat halindeyken, heyette bulunan Eyüp Sabri, Hakkı Behiç, Celal ve Şükrü Beylerin kendisini ziyarete geldiklerini; bunların tutum ve davranışlarından da bazı gariplikler hissettiğini; bu arada Kılıç Ali Beyin odaya gelerek, Mustafa Kemal Paşa'nın kendilerini beklediğini haber verdiğini; heyete onların gitmesini, kendisinin de arkadan geleceğini söylediğini; ancak bu arada trenin kalktığını gördüklerini hatta mebusların da trene yetişemediklerini anlatmaktadır. $^{75}$

Bu arada Mustafa Kemal Paşa'nın faaliyetine devamla Bilecik'e gitmiş olduğunu öğrendiklerini; kendisiyle görüşmek üzere Kazım Paşa'nın gönderildiğini ve Kazım Paşa'nın kendisine şu hususları söylediğini ifade etmektedir:

"Bazl nankör ve hasetçi insanlar kolayllkla muvaffak olabileceklerini sanarak aleyhinizde bazı teşebbüslerde bulunuyorlar. Fakat beni buraya gönderen Mustafa Kemal Paşa'nın sözlerinden anllyor ve öyle kanaat ediyorum ki, fikirlerinden vazgeçti. Bununla beraber şayet kanaatimde yanilırsam ve size karşı fiilen teşebbüslerde bulunulursa, namusumla söz veriyorum, idaremdeki iki piyade firkamla ben de onlara karşı hareket ederim. Tarih ve umumi efkâr önünde maddi ve manevi mesuliyet onlara düşer. Fakat siz takdir edersiniz ki, öyle bir hal karşısında Kuvayı Seyyareye katılacak iki piyade firkamı, öyle bir

${ }^{75}$ Ethem, Hatıralar, s. 137-146. 
tecavüzü başarısızlı̆̆a ulaştırır. Bu itibarla düşman karşısında bulunan kıtalarınızı geri almak ve o cepheyi açmak Yunanlılara firsat bahşeder ki, öyle bir hale sebebiyet vermek sizin vatanperver hislerinize siğmaz, ${ }^{76}$

Ethem de cevaben; düşman karşısındaki kuvvetlerini çekmeye tenezzül etmeyeceğini; ancak bundan sonra, Mustafa Kemal ve arkadaşlarına dost gözüyle bakmayacağını; düşman önünde fiilen arkadan vurulmayı göze aldığını; ancak nefsini koruyacağını; firsat olursa Yunanlılara karşı müdafaada, arkadan vurmak isteyenlere karşı taarruzda olacağını; söyler. ${ }^{77}$

Ethem'in hatıralarına göre; Kazım Bey'in Ankara'ya dönmesinden sonra son bir nasihatte bulunmak üzere; Vehbi, Celal, Eyüp Sabri, Kılıç Ali ve kardeşi Reşit Bey'den oluşan beş kişilik bir mebus heyeti gelmiştir. Ethem'e göre bu heyet, Mustafa Kemal Paşa'nın kendisini avutmak üzere göndermiş olduğu son heyettir. Ethem'e göre heyet; Mustafa Kemal Paşa'nın kendilerine verdiği sözlerin artık bir fenalığa meydan vermemek arzusuna dayandığını zannetmektedir. Hatta heyet, iki taraf arasındaki gerginliğin ortadan kaldırmayı başarabileceğini sanmaktadır. Ethem'e göre heyet tamamen yoklama amaciyla gelmiştir. Ethem heyete; İsmet Bey'in fiilen tecavüz etmek üzere olduğunu, almış olduğu tertibatı da açıklayarak anlatmış ve son olarak şunları söyler:

"Gediz cephesinde Kuvayı Seyyare ile düşman arasında muharebe devam etmektedir. Düşman son aylar zarfindaki tutumunun dışında garip bir ruhla, bizden yani cepheden bazl mevkiler işgal etmek istiyormuş gibi... İşte vaziyet bu! Gidiniz, Ankara'da samimi arkadaşlarınızı ikaz ediniz, hukuki vazifenizi de ona göre ifa ediniz!",78

Çerkes Ethem hatıralarının bundan sonraki bölümleri; çarpışmaya meydan verilmemesi için aldığı tedbirleri; birlik komutanlarıyla yapmış olduğu son bir toplantıy1; İsmet Bey kuvvetleriyle temasın sağlanması; Yunanlılara yapmış olduğu başvuru; Gediz'de Refet Bey kuvvetleriyle yaşanan temas; Yunanlılara iltica teklifi ve iltica; Papulas'ın tedavi sözü; Avrupa'da tedavi için başvurusu gibi bölümleri içermektedir. ${ }^{79}$

\section{Çerkes Ethem Hadisesi Hakkında Diğer Görüş ve Düşünceler:}

\section{Ali Fuat Paşa (Cebesoy):}

Ali Fuat Paşa, Çerkes Ethem'in Yeşil Orduya girmesi için nasıl kandırıldığını şu şekilde açıklamaktadır:

"Dâhili isyanlara karşı teşkilat yapmaktan ibaret olan hedefini çoktan aşmış olan Yeşil Ordu Cemiyeti hakkında Mustafa Kemal Paşa'nın nazarı

\footnotetext{
${ }^{76}$ Ethem, Hatıralar, s. 146-147.

${ }^{77}$ Ethem, Hatıralar, s. 147.

${ }^{78}$ Ethem, Hatıralar, s. 147-150.

${ }^{79}$ Ethem, Hatıralar, s. 150-202.
} 
dikkatini çekmiştim. Üzerinden pek az zaman geçtikten sonra Mustafa Kemal Paşa, cemiyetin kendisinden gizlediği birçok teşebbüsleri haber almış ve derhal dağıtılmasını istemişti. Paşa'nın bu kararı yerinde idi. Fakat buna rağmen cemiyetin Büyük Millet Meclisi içinde taraftarları kalmış, bazı yerlerdeki teşkilatı da faaliyetine devam etmişti. Hatta Çerkes Ethem Bey ve kardeşleri bu teşkilata girmiş ve ona kuvvetli bir mesnet olmuştu. Cemiyet muntazam ordu fikrine de taraftar değildi. Dâhili isyanları bastırmak hususunda ve Demirci savaşlarında milli davaya bir hayli hizmetleri dokunan Çerkes Ethem Bey ve müfrezelerini, hayali çok geniş olan politikacılarımız iğfal etmişler. Yeşil Ordu içinde yine gizli bir teşkilat yapmışlar ve o tarihlerde ihtilafa düşen Anadolu'da yeni gailelerin çımasina sebebiyet vermişlerdi. Daha Adapazarı isyanının bastırıldığının ertesi günü Ethem Bey'i yakindan takip eden bu politikacılar, опи kandirarak Padişaha, Damat Ferit'e ve Ingiliz kumandanlığına mektuplar yazdırmışlardı. Sonraları Ethem Bey bu gizli teşkilatın bir aleti olmuştu. Vaktiyle Yunanlılara karşı kahramanca müdafaa ettiği vatanını bırakarak Yunanlılar tarafina geçmişti. Politikacılar onu vatan hainliğine kadar sürüklemişlerdi, ${ }^{, 80}$

Çerkes Ethem'in Yozgat isyanının bastırılması amaciyla, görevlendirilmek üzere Ankara’ya çağrılması ve daha sonra yaşananlar hakkındaki görüşleri ise şöyledir:

"Ethem Bey müfrezelerinin Ankara'ya çă̆rılmaması için çok uğraşmış̧tım. Gittikten sonra da tedip hareketini yaparken mutlaka yüksek rütbeli bir kumandanin emri altına verilmesini veya herhangi bir siyasi cereyana kaptırılmamasını israrla rica etmiștim. Maatteessüf ricalarımın hiçbirisi nazar-ı itibara alınmamıştı.

"Yozgat isyaninın bastırlmasındaki muvaffakiyetinden dolayı Ankara'nın resmi mahfilinde lüzumundan fazla takdir ve iltifatlara mazhar olan Çerkes Ethem Bey ve müfrezelerinde esasen mevcut olmayan askeri disiplin büsbütün gevşemiști. ",

Garp Cephesi kurulduktan sonra bütün milli müfrezeler lağv olunmuş veya düzenli ordu teşkilatı gibi idare edilmeleri sağlamıştır. Ancak Ankara'dan döndükten sonra tekrar Garp Cephesi emrine giren Ethem Bey ve müfrezelerinin milli hükümet merkezinden aldıkları resmi olmayan yetkilerden dolayı, daha önceden de tahmin edildiği gibi muamele ve idarelerinde daha çok bağımsızlık ve yetki istedikleri anlaşılmıştır. ${ }^{82}$

Çerkes Ethem, Ankara'da Büyük Millet Meclisi salonunda dinleyiciler bölümüne girdiği zaman bütün mebuslar tarafindan ayakta alkışlanmıştır. $\mathrm{Bu}$

${ }^{80}$ Ali Fuat Cebesoy, Milli Mücadele Hatıraları, Temel Yayınları, İstanbul, 2010, s. 515-516.

${ }^{81}$ Cebesoy, a.g.e., s. 516., s. 530.

${ }^{82}$ A.g.e., s. 530. 
ve buna benzer olaylar kendisini tamamen şaşırtmış ve şımartmıştır. Ethem Bey hastalandığı zaman, yine mecliste görmüş olduğu müstesna muamele ile bir mebus hakkında istediği iznin, meclis tarafından işleme konulması ve derhal kabul edilmesi açıklanması kolay şeyler olmamıştır. Bu kapsamda Çerkes Ethem'in meclis başkanlığına çekmiş olduğu telgraf şu şekildedir:

\begin{abstract}
"Ankara'da Meclis-i Kebir Riyaseti Celile'sine; $\quad$ Meclis-i Kebir azasindan berayı teşkilat bir hafta mezuniyetle Adapazarı ve havalisine gönderilen İzmit Mebusu Fuat Bey'in vazifesi müddeti mezuniyeti dâhilinde ifa edilemeyeceğinden lütfen temdidi müddetle müsaade-i alilerin lüzumu maruzdur efendim.”21 Teтmuz 336, Umum Kuvayı Tedibiye Kumandanı Ethem
\end{abstract}

Ali Fuat Paşa'ya göre; gerçekte Ethem Bey gibi milletin içinden çıkmış, o güne kadar şöhret ve başarılarını hakkıyla kazanmış biri, başka türlü ödüllendirilmiş olsaydı milli iradeye karşı hain durumuna düşmez ve kazandığ1 şöhreti korurdu. Bu gibi muameleleri hazmetmek kabiliyetinden yoksun olan Ethem gibi kişilerin, gün gelip kabına sığmayıp taşacak faaliyetlerinin normal karşılanması gerekmektedir. ${ }^{83}$

Ankara'dan geniş yetki ve nüfuzla Garp Cephesine geri dönen Ethem, Ali Fuat Paşa tarafindan Demirci cephesindeki harekât için görevlendirilmiştir. Ethem, yeni teşkil edilen ordu birlikleriyle koordineli olarak yapılan harekâtı, almış olduğu emirler çerçevesinde başarıyla icra etmiştir. Hatta hükümetin isteği üzerine Kuvayı Seyyarenin yeniden düzenleneceği kendisine söylenildiği zaman açıklamaları sükûnetle ve dikkatle dinlemiş yeni durumu kabulde tereddüt göstermemiş̧ir. Çok hasta olması nedeniyle yerine mantıklı olarak kardeşi Tevfik Beyi vekil olarak bırakmış, bir müddet Eskişehir'de tedavi gördükten sonra Gediz taarruzu için çağrıldığında, hasta olmasına rağmen görevinin başına gelmiştir. $\mathrm{Bu}$ dönemde kazandığı başarılar, Cephe Kumandanı tarafindan gerçekten takdire şayan bulunmuştur. Zira Demirci cephesinde bütün milli kuvvetler dağılmış olduğu halde, düşmanın içlerine kadar sokularak kendisinden dört beş misli üstün Yunan piyade firkasını mağlup etmeyi başarmış, bu durum cephe ve yeni kurulan ordu üzerinde iyi bir tesir yaratmıştır. ${ }^{84}$

Ali Fuat Paşa'ya göre; eğer bu dönemde Kuvayı Seyyare itaat ve disiplin altına alınmamış olsaydı, arkasından iki bin beş yüz kişiyi sürükleme imkânına sahip olan Ethem, böyle bir kuvvetle İnönü muharebelerinde ordumuzu arkasından vurabilir veya memleket içine dağılarak yeni idareyi zayıflatabilirdi. İsyan bastırıldıktan sonra “Ethem'in isyanı zamanında

\footnotetext{
${ }^{83}$ A.g.e., s. 530-531.

${ }^{84}$ Cebesoy, a.g.e., s. 531-532.
} 
olmuştu. Çünkü Ethem hadisesi başka türlü halledilemezdi" denilmiştir. Ali Fuat Paşa bu görüşe katılmamaktadır. Ona göre; bir hadisenin neticesine göre hüküm vermek doğru değildir; Ethem'in isyanı ile beraber Yunan ordusu yalnız İnönü istikametinde taarruza geçseydi, Ethem içerilere kadar nüfuz ederek yeni milli idare aleyhinde birçok fenalıklar yapabilirdi. ${ }^{85}$

Ali Fuat Paşa'nın "Gediz Taarruzu” hakkındaki görüşleri ise şu şekildedir:

"Askeri bakımdan Gediz baskını zorunluydu. Erkan-ı Harbiye-i Umumiye Vekâleti, bilhassa cephanemizin azlığından dolayı önce bu harekâta razı olmak istememişse de, sonradan cephanenin Italya'dan temin olunduğu haberi alininca muvafakat etmişsi...

"Alayund'da yapılan toplantıda; Arif ve Çerkes Ethem Beyler harekete taraftar olduklarını derhal bildirmişlerdi. Kazım ve İzzettin Beylerin de bazl itirazlarla birlikte sonradan taraftar olduklarl anlaşılmuştı...

"Gediz taarruzu kumanda, sevk ve idare bakımından çok güçlü bir askeri harekât olmuştu. Garp cephesi üstün bir düşman karşısında yanların zorunlu olarak zaylf bıraktıktan sonra, bütün kuvvetinin yarısını toplayarak cephenin ortasında düşmanın merkezine doğru bir yürüyüs yapmıs, bir firkasını yalnız yakalamıs ve bunu mağlup ederek geriye atmıştır. Sonra düşmanın hiçbir tehdidine uğramadan eski vaziyetini almıştı. En muntazam orduların güçlükle başarabileceği bir hareketi, o tarihlerde yeni kurulmaya başlamış küçük milli ordumuzun başarması; ehliyet, cesaret ve milli bir gayrete sahip olduklarını göstermeğe yeterli gelmişti. ${ }^{, 86}$

\section{Kazım Paşa (Özalp):}

Kazım Bey (Paşa, Özalp), Gediz muharebesinden sonra ortaya çıkan tartışmalara değinerek; Ethem ve arkadaşlarının; Gediz muharebesinde nizamiye kıtalarının vazifelerini yapmadıkları; Kuvayı Seyyareye gereken yardımlarda bulunmadıkları şayialarını çıkararak, nizamiye kıtalarını gözden düşürmeye çalıştıklarını belirtmektedir. Buna karşılık nizamiye kıtaları kumandanlarının da; Kuvayı Seyyareyi ciddi bir şekilde muharebeye girmedikleri, harp meydanını bırakarak kaçtıkları, şeklinde beyanlarda bulunduklarını ifade etmektedir. Kuvayı Seyyare ileri gelenlerinin özellikle subayları gözden düşürmek amaçlı bu faaliyetlerinin giderek arttığını; Cephe Kumandanı Ali Fuat Paşa'nın ise, her iki birliğin görevini layıkıyla yapmış olduğuna dair çabalarının yetersiz kaldığını açıklamaktadır. ${ }^{87}$

\footnotetext{
${ }^{85}$ A.g.e., s. 532-533.

${ }^{86}$ A.g.e., s. 557-567.

${ }^{87}$ Kazım Özalp, Milli Mücadele 1919-1922, Türk Tarih Kurumu Yayınları, Ankara, 1998, s. 166.
} 
Kazım Bey aynı zamanda Karesi Mebusu olması nedeniyle, o dönem için kumanda ettiği Ertuğrul Grubundan ayrilarak, Mustafa Kemal Paşa'nın izniyle 22 Ekim 1920'de (Milli Mücadele 1919-1922'ye göre), 22 Kasım 1920'de (Yakın Tarihimiz, s.326'ya göre) Büyük Millet Meclisine katılmıştır. Kumanda ettiği Ertuğrul Grubu da 26 Aralık 1922 tarihinde kaldırılmıştır. Bu dönemde Çerkes Ethem ve Kardeşlerinin faaliyetlerini şu şekilde aktarmaktadır:

“Çerkes Ethem'le kardeşleri, Refet Bey'in Cenup Cephesine tayinine itiraz ediyor ve müstakil kalmak istiyorlard. İsmet Bey, Kuvayı Seyyarenin tamamen düşmanla meşgul olmasinı ve cephe gerisindeki işlerle alakadar olmamalarını temin düşüncesiyle, bir Kütahya bölgesi kumandanlığı kurarak, Miralay İbrahim Bey'i bu bölgenin kumandanliğına tayin etmişti. Bu sirada Çerkes Ethem Ankara'da bulunuyor ve Gediz bölgesindeki kuvvetlere kardeşi Tevfik Bey kumanda ediyordu. Bu arada Tevfik, cephenin selameti namina yapılan bütün teşkilata daima itirazda bulunuyordu. Bu arada cepheden gönderilen bölge kumandanını dahi geri yollamıştı. Ayn zamanda bütün emirlere ehemmiyet vermiyor, cephe ile irtibatını kesmiş bulunuyordu. Durum pek nazik bir şekle girmişsti. Cephe kumandanının ciddi gayretlerine rağmen, Tevfik'i yola getirmek mümkün olmadl. Garp cephesini tanımıyor, Meclis Riyasetine doğrudan raporlar gönderiyordu. O strada Ethem ve kardeşi Reşit Bey Ankara'da bulunuyorlardl. Her iki kardeş de Ankara'da yaptıkları görüşmelerde, Kuvayı Milliye'nin askeri inzibata tabi olamayacağını ve Tevfik'in hareketlerinde haklı olduğunu söylüyorlardl. ",88

Kazım Bey (Paşa, Özalp) bundan sonraki açıklamalarında, Nutuk'ta da belirtilen ve durumun çözümlenmesi amacıyla Eskişehir'de yapılan toplantı hakkında bilgiler vermektedir. Ancak bu toplantı bilindiği üzere belirlenen amacı sağlayamamıştır. Toplantı sonunda, Kazım Bey'in Reşit Bey'le beraber Kütahya'ya gitmesi ve Ethem'in cephe kumandanlığ 1 emirlerine uyması için uyarılması kararlaştırılmıştır. Kazım Bey, Reşit Bey'le beraber Kütahya'ya ulaştığı zaman Ethem henüz oraya gelememiştir. Ancak birkaç saat sonra gelmiş, Gediz'de bulunan kardeşi Tevfik de toplantıya katılmak üzere Kütahya'ya çağrılır. Meselenin beraberce görüşülmesi esnasında her iki kardeş, cephe kumandanının emirlerine uyacaklarını beyan ederler. Yalnız, Refet Bey'in Konya'dan alınmasında ssrar ederler, Kazım Bey'in kendilerine kumandan olmasını isterler. Kazım

${ }^{88}$ Özalp, a.g.e, s. 166-169. 
Bey ise; bu fikirde ısrar etmelerinin doğru olmadığını, onların ısrarıyla kumandayı üzerine almasının askeri usullerle bağdaşmadığını, böyle bir durumu şahsen kabul edemeyeceğini belirtir. Zira mahiyetin talebiyle kumandanlık almak, onların emrine girmek demektir. Ertesi gün Reşit Bey ve Hacı Şükrü Beyle beraber Eskişehir'e dönmüşler ve konuşulanları İsmet Bey'e anlatmışlardır. Kazım Bey'in kanaatine göre mesele geçici olarak halledilmiştir. ${ }^{89}$

Kazım Bey'in, Yakın Tarihimiz Dergisine vermiş olduğu mülakatta ise, toplantı esnasında geçen görüşmeler daha teferruatlı olarak anlatılmaktadır. Kazım Bey, Çerkes Ethem'e "bu haller ne olacak?" diye sorduğunda; hiddetle; "Kuvve-i Seyyare aleyhinde hazırlıklar yapılmaktadır. Konya'da Refet Bey, bu maksatla süvari teşkilatı yapıyor. Garp Cephesi Karargâhindan sizan haberlere göre, Nizamiye Kuvvetleri, Kuvve-i Seyyareyi ezmek için hazırlanıyor. Refet Bey'le de aramızda izzet-i nefis meselesi oldu. Mustafa Kemal Paşa onu korumayl tercih etti. Ankara'daki hükümet acizdir. Reşit, bizi oyalad. Kuvve-i Seyyare aleyhindeki tertibat devam ederken, nihayet harekete geçer, kuvvetlerimle evvela Konya üzerine yürür ve oradan Refet Bey'i önüme katarak, Ankara'ya kadar giderim” demiştir. Kazım Bey ise cevaben şunları söyler :

"Kuvve-i Seyyare aleyhine hiçbir tertip olmadı̆̆ını biliyorum. Muntazam ordu teşkilatının süratle yapılmasına çalışılıyor. Milis teşkilatıyla büyük kuvvetlerin vücuda gelemeyeceğini takdir edersiniz. Muntazam ve kuvvetli bir ordu teşkilatının, memleketin bütün kaynaklarından faydalanmakla vücuda getirilebileceği de malumdur. Kuvve-i Seyyarenin dağlmasi fikri yoktur. Fakat, memleket dahilinde irtibat zabitleri vasıtasıly (Ethem, hükümete karşı sorumlu saydırmayıp, doğrudan doğruya kendi emrinde bulundurduğu bu irtibat zabitleri vasıtasıyla, halka her istediğini yaptırır, hatta dilediği şekilde ceza verdirir veya arzu ettiği miktarda vergi ve asker dahi toplard $k i$, aleyhindeki şikayet konularından biri de buydu.) Kuvve-i Seyyare için, er toplamak, yeni kuvvetler teşkil etmek, firarileri takip etmek, para ve sair yardımları almak, muntazam ordu için lazım olan ikmal efradı vesaireyi toplanmasını güçleştirir. Bu sebepten dolayl, Kuvve-i Seyyarenin cephe gerisindeki faaliyetlerini kayıt altına almak lüzumu hasıl olmuştur. Kuvve-i Seyyarenin Cephe Kumandanlı̆̆ına karşı maksatlarını cebren yaptırmă̆a teşebbüs etmesi en tehlikeli bir yoldur. Bu memleket geniş bir sahadir. Her tarafinda, klymetli kumandanlar, subaylar, silahl kuvvetler ve halk vardır. Yunanlıları bir tarafa bırakıp, kendi hükümetimize karşı yapllacak bir harekete lakayt kalmazlar. Umumi infial uyandırır. Bu, Kuvve-i Seyyarenin itibarını düşürür. Karşı hareketlere ve daha bazı hadiselere sebep olur. Düşman bundan istifade eder. Sonunda kurtarmağa çalıştığımız memleket mahvolur."

${ }^{89}$ A.g.e, s. 167-169. 
Kendisini dikkatle dinleyen Ethem ise bir süre düşündükten sonra; " $B u$ haller olmamalı idi. Biz sebebiyet vermedik. Her şeyi idareye çalışacağım ama Refet Bey'i Konya'dan alsınlar.” demiştir. Kazım Bey, Kuvayı Seyyare içinde de, Yunanlıları bir tarafa bırakarak, askerlerimizin üzerine ateş etmeye hamiyeti ve vatanseverlikleri müsait olmayan birçok kimseler bulunduğu kanaatindedir. Ethem'in bu gibileri de düşündüğünü anlamıştır. Daha sonra Eskişehir'e döner ve durumu İsmet Bey'e anlatır. İsmet Bey, Ethem'in Yörük Ali ve Demirci Efe'ye ve diğer milli kuvvetler kumandanlarına birleşerek, nizamiye kuvvetlerine karşı vaziyet almaları için yazmış olduğu bir telgrafı Kazım Bey'e gösterir. Ankara'ya döndügünde de tüm gelişmeler hakkında Mustafa Kemal Paşa'yı bilgilendirir. Mustafa Kemal Paşa da kendisine; "Bu iş müsademeye varacak gibi görünüyor..." şeklinde beyanda bulunur. ${ }^{90}$

Kazım Paşa'nın, Yakın Tarihimiz Dergisinde yapılan mülakat esnasında ilettiği telgraflar Ek'lerdedir.

EK-2 (Çerkes Ethem'in Demirci Mehmet Efe'ye Telgrafi)

EK-3 (Çerkes Ethem'in B.M.M. ve Garp Ordusuna Çektiği Telgraf)

EK-4 (9 Ocak 1921 Tarihinde Çerkes Ethem İmzalı, Yunan Uçağından Köylere Atılan Telgraf)

\section{İsmet Paşa (İnönü):}

İsmet Paşa da hatıralarında Çerkes Ethem hadisesine geniş yer vermektedir. Yozgat isyanının kanlı bir şekilde bastırılmasından sonra, Ethem Bey ve kuvvetlerinin Ankara'ya dönüşlerinde beraberlerinde çok sayıda eşya ve hayvan getirdiklerini, bunları Ankara'da kurulan panayırlarda sattıklarını ifade etmektedir. Olup bitenlerin kendileri tarafindan sadece üzüntüyle seyredildiğini, hiçbir şey yapamadıklarını acı bir hatıra olarak aktarmaktadır. İç isyanların bastırılmasında muntazam kuvvetlerden çok Kuvayı Milliye'nin başarılı olmasının ordu aleyhinde bir hava yarattığını, Haziran sonlarında Yunan ileri harekâtının bu durumu büsbütün karıştırdığını, herkesin dilinde "Muntazam ordudan hayır yoktur" sözlerinin dolaşmaya başladığını belirtmektedir. İsmet Paşa'ya göre; Özellikle Yozgat isyanının bastırılmasından sonra, Kuvayı Seyyarenin ve Çerkes Ethem'in itibarı büsbütün artmış; Ethem ve Reşit Beyler ordu aleyhine açık propagandalara başlamış, yeni esaslar üzerinde, milis esaslarına göre halk ordusu tertip etmek gereğinden bahsetmeye başlamışlar ve kendilerine birçok taraftar da bulmuşlardır. ${ }^{91}$

${ }^{90}$ Yakın Tarihimiz, Cilt II, s. 362-363

${ }^{91}$ İsmet İnönü, Hatıralar, Bilgi Yayınları, C.I, Ankara, 1992, s. 203-212. 
Muntazam ordunun kurulması için yoğun çaba gösterildiği bir sırada ve ordu aleyhindeki dedikoduların bertaraf edinilmesine çalışılırken, Garp Cephesi Kumandanı Ali Fuat Paşa; Gediz'de bulunan bir Yunan tümenine taarruz etmeyi tasarlamış ve bunu Erkan-1 Harbiye-i Umumiye 'ye bildirmiştir. İsmet Paşa'ya göre Ali Fuat Paşa'da bu taarruz için uyanan heves, söz konusu tümenin münferit bir halde bulunmasından kaynaklanmaktadır. İsmet Paşa, yapmış olduğu kuvvet mukayesesi çerçevesinde Erkan-1 Harbiye-i Umumiye Vekili olarak, planlanan taarruza uzun süre karşı çıkar. Durumu yerinde görmek üzere Eskişehir'e gider, orada Ali Fuat Paşa ile görüşür ve birlikte harekâtı ertelerler. Ancak cephe kumandanı taarruz fikrinde 1srar edince Mustafa Kemal Paşa araya girmiş, hepsini dinlemiş ve bu şekilde bir harekâtın yapılmasını, belirli usuller altında onaylamış, "Pekâlâ yapınız" demiştir. ${ }^{92}$

İsmet Paşa'ya göre; Ali Fuat Paşa'nın, Ethem Bey kuvvetleri ile beraber tertiplediği bu taarruz harekâtı başarılı olamaz. Gediz hadisesi üzerine Mustafa Kemal Paşa, bir vesile ile Ali Fuat Paşa'yı Ankara'ya çağırır. Ali Fuat Paşa Kuvayı Milliye teşkilatını itibarlandırmak için elinde bir filinta olduğu halde, Kuvayı Milliye elbiseleri ile Ankara'ya gelir. Mustafa Kemal Paşa ile görüşürler ve Ali Fuat Paşa, Moskova'ya sefir olarak gönderilme fikrini kabul eder. Daha sonra düzenli ordunun kurulması için Mustafa Kemal Paşa tarafindan kesin bir emir verilmiş, Erkan-1 Harbiye-i Umumiye Vekilliği üzerinde kalmak üzere, Garp Cephesi Kumandanlığına İsmet Paşa, Dâhiliye Vekâleti üzerinde kalmak üzere, Cenup Cephesi kumandanlığına da Refet Paşa tayin edilmiştir. 8 Kasım'da gerçekleşen bu tayin sonrası İsmet Paşa 10 Kasım'da Bilecik'e gelmiş, daha sonra cephe karargâhının bulunduğu Eskişehir'e geçmiştir. Burada takip edeceği politikayı ve kumanda usulünü şu şekilde açıklamaktadır:

"Şimdiye kadar Kuvayl Milliye ile ordu vazifelerini bir arada mezcedilmiş olarak ifa ediyorduk. Büyük Millet Meclisi teşekkül etmeden evvel gerek Kuva-yl Milliye'ye yardim meseleleri gerek ordunun idaresi, ordunun cephe vazifeleri özellikle mali bakımdan sivil vazifeyle karlşık bir haldeydi. Anadolu Milli Hükümeti teşekkül ettikten sonra vaziyette, sevk ve idarede esasl bir değişiklik olmuştur. Şimdiye kadar her kumandan kendine ayrllmış olan bölgelerden efratlarını alır, kitasının iaşesini, teçhizatını kendisi temin eder, ordunun idaresi hükümetle bir ilgisi olmaksızın kumandan tarafindan halkla temas edilerek doğrudan doğruya yapilırdı. Artık bu usulü terk edeceğiz. Bundan sonra ne istediğiniz olursa Garp Cephesi Kumandanlığından isteyeceksiniz. İhtiyaçlarınız cephe kumandanllğınca temin olunacaktır. İaşenin, teçhizatın ve ordu maaşının temininde bu usule riayet edilecektir. Artık

92 İnönü, a.g.e., s. 213. 
ordunun halkla temasl olmayacaktır. Halktan asker almak gerekirse bildireceksiniz. Bunların hepsini ben temin edeceğim. Kimseden on para alamazsınız ve kimseyi hiçbir sebepten dolay tavzif edemezsiniz. Vatandaştan şikâyetiniz varsa bunlart usulüne uygun bana bildireceksiniz. Şikâyetler devletin resmi, adli mercilerinde, ordunun adli mercilerinde yani Divan-l Harplerde tetkik olunacak ve gereği yapılacaktır. Hiç kimseden para almak yok, hiçbir vatandaşı kendiliğinizden askere almak yok, hiçbir vatandaşa eza etmek yok. Bugüne kadar yapılmış muamelerin hiç birini aramayacağım. Bundan sonra yapacaklarinizin hesabinı sorarım." 93

İsmet Paşa bu beyanattan sonra, o güne kadar şartlardan ve ihtiyaçlarından dolayı vazifeleri dişında birçok işlerle uğraşmaya mecbur kalmış olan kumandanların rahatlamış olduklarını, ancak böyle bir uygulamaya girişmekle daha ilk günden Kuva-yı Seyyare ile çatışmaya başladığını belirtmektedir. Birinci Kuva-yı Seyyare Kumandanı olarak tefrik edilen Ethem Bey ise, her tarafa ellerinde şifreler olan subaylar göndermek suretiyle insanları ikna etmeye, davetle asker almaya, sivil makamlara bask1 yapmaya, mukavemet gösterenlere karşı müfrezeler yollamaya ve zorla iş yaptırmaya devam etmektedir. Ethem Bey ile aralarında geçen bir maaş mevzusuna da değinerek, usulsüzlükleri tespit ettiğini açıklamaktadır. Ancak tüm bunlara rağmen Ethem Bey'in görevlendirdiği subaylar faaliyetlerine devam ederler. İsmet Paşa'nın düzenli orduya yayınlamış olduğu emirler, Kuva-y1 Seyyare aleyhinde bir tertip olarak algılanır, kuvvet mevcutları gönderilmez, her isteklerinin temin edileceği belirtilmesine rağmen sürekli evhama kapilırlar. ${ }^{94}$

4 Aralık 1920 tarihinde, Eskişehir'de yapılan toplantıya kadar olan dönemde İsmet Paşa'nın hatıralarından tespit edilen Çerkes Ethem ve kardeşleriyle ilgili problem sahalarını şu şekilde özetlemek mümkündür:

Çerkes Ethem ile ilk çatışma, düzenli ordunun gereklerinin yerine getirilmesi hususlarında çıktı. Kıta ve cephane mevcutları istenmesine rağmen cephe kumandanına durum bildirilmedi. Simav bölgesine gönderilen İbrahim Bey, Kuva-y1 Seyyare Kumandan Vekili Tevfik Bey tarafından kabul edilmedi ve geri gönderildi. Tevfik Bey tarafindan günlük raporlar verilmemeye başlandı ve Garp Cephesi Kumandanlığı ile ilişki kesildi. Cephe raporları kimi zaman Meclis Başkanı Mustafa Kemal Paşa'ya kimi zaman da Ankara'da bulunan Çerkes Ethem'e gönderilmeye başlandı. Ankara'da Ethem Bey dışarıdan, kardeşi Reşit Bey meclis içerisinde ordu aleyhinde propagandaya yoğun bir şekilde devam ettiler. Yeşil Ordu Ethem

\footnotetext{
${ }^{93}$ A.g.e., s. 214

94 İnönü, a.g.e., s. 214-215.
} 
ilişkisi bağlamında da; "Görüyorsunuz, muntazam ordu bir işe yaramıyor, o devir geçmiştir. Rusya'da olduğu gibi milli bir ordu teşkil etmeliyiz." Propagandası yaygınlaşmıştır. ${ }^{95}$

İsmet Paşa, 4 Aralık günü yapılan toplantıda göreve başladığı günden itibaren Ethem Bey ve kardeşi Tevfik Bey'le aralarında olan gelişmeleri anlatmaktadır. Kendilerinden ne beklediğini, ne istediğini, onların nasıl davranmaları gerektiğini açıklar. Reşit Bey'in, bir faaliyet yapılmadan önce kardeşlerinin de fikirlerinin alınması gerektiği şeklinde konuşması üzerine, bir cephe kumandanının yetkilerini ve nasıl emir vermesi gerektiğini izah eder. Emrinde bulunan bütün birliklerin kendisi için aynı öneme sahip olduğunu vurgular. Reşit Bey'in halen tutarsız davranış ve konuşmalarda bulunması üzerine Mustafa Kemal Paşa araya girip, İsmet Paşa'nın dediklerini uygulayıp, uygulamayacaklarını sorduğunda; İsmet Paşa, aşağıda belirtilen konuşmayı yaparak, toplantının amacına ulaşmasını sağladığını ifade etmektedir.

"Paşam, şimdi benim emrim altında bulunan kumandan ile aramızda bir mesele var. Yani biri bana itaatsizlik etmiş. Siz bu meseleyi halletmek istiyorsunuz. Ama bir çare bulamıyorsunuz. Ben, size, emrim altında bulunan bir kumandan bana isyan etti, ben bunu halledemiyorum, siz buna karışın dedim mi? Böyle bir tatsızlık oldu. Fakat hala kaniyim ki, ben bu işi düzeltirim. Bu cephede emri kumandayı muhafaza ederim. Ama olabilir ki, hakikaten yapamam. O zaman siz, yapamıyorsun, dersiniz. Veyahut bu meselenin halli benim kuvvetimi aştl, aşlyor derim. Müdahale edersiniz, istediğinizi yaparsınız. Ama ben size öyle bir şey söylemedim. Bu hususta henüz kimseye karşı aczimi itiraf etmiş ve hiç kimsenin bana ait olan bu vazifenin yapılmasına delaletini rica etmiş değilim. Ben bu meseleyi halledeceğim."

$\mathrm{Bu}$ konuşma üzerine Mustafa Kemal Paşa, "Evet doğru söylüyor, bakalım nasıl düzeltir? Garp Cephesi Kumandanının bu mevzuda bir şikâyeti yok" demiştir. Reşit Bey ise büyük bir telaş içerisinde; "Aman bırakma Paşam, çok fena olacak" diye çırpınmaya başlamış, daha sonra Kazım Bey ile Reşit Beyin, Ethem ile görüşmelerde bulunmak üzere Kütahya'ya gönderilmesi kararlaştırılmıştır. ${ }^{96}$

İsmet Paşa'nın hatıralarından son olarak, 29 Aralık'ta, yani Çerkes Ethem isyanının bastırılmaya başlanmasının ertesi günü, cephelerde meydana gelen gelişmeleri dikkate alarak, tümen komutanlıklarına yayınlamış olduğu emri alıntılamanın uygun olacağı değerlendirilmiştir. Böylece Ethem'in düzenli ordu birliklerine karşı göstermiş olduğu gerçek tavrın anlaşılması da mümkün olabilecektir.

\footnotetext{
${ }^{95}$ A.g.e., s. 216-225.

96 İnönü, a.g.e., s. 225-229.
} 
"1. Kuvayı Seyyare Kumandanı Ethem imzasiyla bugün meclis riyasetine ve kumandanlara çekilen açık telgrafta Yunanlılara karşı ve memleketin kuvvet ve muvaffakiyetini zaylf gösteren bir lisan kullanılarak Büyük Millet Meclisi hakkında hürmet ve itaatle katiyen kabili telif olmayan isnat ve tecavüzatta bulunmakta ve Istanbul'dan gelip Anadolu'ya iltihak eden heyetin güya müsait sulh şeraiti getirdiği gibi hilafi hakikat beyanat neşir olunmaktadır. Bu beyanat kendileri tarafindan ahaliden hodbehot para toplanmamasını, kendileri tarafindan asker alınmamasını ve ahali hakkında idam cezasının ancak Istiklal Mahkemeleri vasitasiyla hüküm ve infaz olunabileceğini ve ordunun muntazam teşkilatına ve zapturapta riayet edilmesini şiddetle talep eden Büyük Millet Meclisi Hükümetine karşı alenen isyan mahiyetindedir.

Bu hususta Büyük Millet Meclisinden yeni bir emir alamadiysam da sarahaten ilanı isyan edenlerin her türlü tecavüzata klyam etmelerine de bir mani kalmamıs demek olup, bu telgraf namede istihdaf edilen gaye tıpkı Damat Ferit Hükümetinin söylediği gibi milletin mukavemetini bertaraf ve Orduyu inhilal ettirecek bir propagandaya tevessül edildiğini göstermektedir.

Isyan istihzaratının hedef ve vüsatı ve peyderpey tavazzuh edecek mahiyete karşı milletin vasıtai asliyesi ancak Ordunun iğfalata karşı mukavemeti vatanperveranesi, heyeti zabitanin gerek tecavüzatı müselleha ve gerekse hululü müfsidaneye karşı teyakkuzlarıdır.

2. Kuvayı Milliye efradına, hayatları için tehlike olduğu evhamı altında millet aleyhine muharebe etmek için yemin ettirmişler ve ordudan ele geçecek zabitanın öldürülmesini tekarrür ettirmişlerdir.

3. Askerin konacă̆ ikamet mahallerinde ahaliden propagandacılar tayin etmişlerdir. Bunlardan haber alınabilenlerden ikisi Kütahya'da Ishak Fakıh mahallesinde uzun boylu, zaylf kırmızı yüzlü, az ve siyah ter bıyıkl, belinde silahlı Mehmet oğullarından Ahmet oğlu Hüseyin, diğeri aynı mahalleden mavi şalvarlı, yeşil yakalı kaputlu, başında kırmızı fes ve kırmızı mendil olan Hüseyin oğlu Süleyman, civar köylere asker içine gönderilmişlerdir. Gerek merkumlar ve gerek emsali müfsitler ordu içinde yakalanır yakalanmaz derhal kurşuna dizilmelidir."

İsmet Paşa, 31 Ocak tarihinde, Kütahya'dan harekete geçmeden önce Ethem'e son bir ikaz telgrafı çeker, ancak şu cevabı alır: "Büyük mücadelelere girmiş zevatta hayat korkusu yoksa Uşak cephesine buyurunuz. Böyle olduğunuzu, bu liyakatte olduğunuzu ispat ediniz. Taarruzunuzu bekliyorum. ${ }^{, 97}$

\section{Sonuç:}

"Çerkes Ethem Hadisesinin Nutuk Temelli" incelenmesi yap1lırken, Mustafa Kemal Paşa'nın, 1927 tarihli Nutuk adlı eseri esas kabul edildi.

${ }^{97}$ A.g.e., s. 235-238. 
Nutuk'ta Çerkes Ethem ile ilgili belirtilen hususlar özetlendi ve bazı bölümler ise aynen birer olgu olarak alındı. Daha sonra Çerkes Ethem hakkında yazılan eserler incelendi; Cemal Kutay'a ait olan eserlerde, yazarın yapmış olduğu yorumların fazlalığı ve kendi görüşlerini yansıtması göz önüne alınarak; 1962 tarihli "Çerkes Ethem 'in Hatıralart" adlı eser, tarihi bir belge niteliğinde olarak kabul edildi. Bu eserlerin yanında; hem Mustafa Kemal Paşa, hem de Çerkes Ethem ile çok yakından temas etmiş, birlikte görev yapmış olan; Ali Fuat Paşa'nın "Milli Mücadele Hatıraları", Kazım Paşa'nın "Milli Mücadele 1919-1922”, İsmet Paşa'nın "Hatıralar” adlı eserlerinden yararlanıldı. Söz konusu eserlerde, özellikle Çerkes Ethem ile ilgili bölümler incelendi; Mustafa Kemal Paşa'nın Nutuk adlı eseri ile Çerkes Ethem'in Hatıraları arasında çelişkiler araştırıldı. Mustafa Kemal Paşa'nın değerlendirmeleri ile Çerkes Ethem'i isyana yönelten unsurların tespitine çalışıldı.

Nutuk'ta ilk olarak Çerkes Ethem hadisesi, Yeşil Ordu ile olan ilişkisi çerçevesinde geçmektedir. Yapmış olduğumuz inceleme esnasında Ethem bu durumu doğrudan yalanlamaktadır. Ancak, dönemin özellikleri ve Ethem'in Bolşevik hayranlığı ile elinde mevcut iki bin kişiye yakın kuvvet dikkate alındığında; meclis içinde Mustafa Kemal Paşa karşıtları, Ali Fuat Paşa'nın da belirttiği “...hayali çok geniş politikacılar”, özellikle Ankara'da bulunduğu günlerde Ethem'i yanlarına çekmek için her yola başvurmuşlardır. Zaten Bolşevik hayranı olan Ethem'in bunların yanında yer alması, kendilerine askeri gücü de olan siyasi bir üstünlük sağlayacaktır. Dolayısıyla, Ethem'in kesinlikle Yeşil Ordu ile ilişkisinin olduğu tespit edilmiş̧ir. Bu tespitte; "İliş̧i kurduğu kişiler, bu kişilerin uygun bir zamanı bekler oluşu, Seyyare-i Yeni Dünya Gazetesindeki mülakatları" gibi olgular önemli birer etken olmuştur.

Ethem'in, Yozgat isyanının bastırılması için Ankara'ya gelişi, karşılanışı, mecliste ve Ziraat Mektebinde ağırlanışı ile Ankara'da, başta Mustafa Kemal Paşa olmak üzere, Fevzi ve İsmet Paşalar ile yapılan toplantı; gerçekten ilgi çekici özelliklere sahip, incelenmeğe değer bir durumdur. Zira Ethem'in hatıralarını Nutuk adlı eseri okuduktan sonra yazmış olduğu bir gerçektir. Hatta hatıralarında bazı yerlerde bizzat Nutuk'a cevap olduğunu da belirtmektedir. İsmet Paşa, "Hatıralar" adlı eserini, Ethem'in hatıralarından sonra kaleme almış, Ankara'da yapılan toplantıya ise hiç yer vermemiştir. Nutuk'ta da bu toplantıdan bahsedilmemektedir. Oysa Ethem, bu toplantıda söylediklerini hatıralarında açıça dile getirmektedir. Dolayısıyla, Ethem'in toplantıya ilişkin anlatmış olduğu hikâyelerin doğruluk derecesini, aktardığı sahneler ve Milli Mücadele'nin en üst düzey liderlerinin tutumları hakkında söylediklerini net olarak kanıtlamak mümkün değildir. Ancak, Nutuk'ta açık olarak veya satır 
aralarında belirtildiği gibi; Ethem'in Ankara'da bulunduğu sürede bazılarının abartılı iyi niyet gösterilerinde bulunması, o dönem için Ethem kuvvetlerine olan ihtiyaç gibi hususlar göz önünde tutulduğunda gerçeklik payının çok da az olmadığını değerlendirmek mümkündür.

Ankara Valisi Yahya Galip Bey hadisesinin Nutuk ve Ethem'in hatıraları ile örtüştügünü değerlendirmek mümkündür. Burada Ethem'in, "şayet soruşturma gerçekleşseydi, Mustafa Kemal Paşa dahi yargılanacaktı" şeklinde, yargılama süreci hakkında yapmış olduğu değerlendirmeye, gerçekçi bir şekilde bakıldığında katılmamak mümkün değildir. Ancak Ethem'i bu cesarete iten etkenlerin; kendisine gösterilen aşırı ilgi ve alakayı hazmedemeyişinden kaynaklandığ 1 ortadadır. Ali Fuat Paşa'nın belirttiği gibi "Ethem gibi milletin içinden çıkmış, o güne kadar şöhret ve başarılarını hakkıyla kazanmış biri, başka türlü ödüllendirilmiş olsaydı milli iradeye karşı hain durumuna düşmez ve kazandiğı şöhreti korurdu. Bu gibi muameleleri hazmetmek kabiliyetinden yoksun olan Ethem gibi kişilerin, gün gelip kabına sı̆̆mayıp taşacak faaliyetlerinin normal karşılanması gerekir."

Ethem'in Yozgat isyanının bastırmasından sonra kabullenmekte zorlandığı esas mesele, düzenli orduya geçiş çalışmalarıdır. Milli Mücadele'nin başlangıç safhasından itibaren, hem cephede, hem de ülke içerisindeki isyanlarda genellikle kendi başlarına buyruk hareket etmeye alışmışlardır. Tesis edilecek yeni bir emir-komuta sisteminin, kendi otoritelerini sarsacağ1 endişesi, düzenli ordu sistemine karşı her türlü itaatsizliğin, düzenli birlikler aleyhinde propagandanın başlamasına neden olmuştur. Garp Cephesinde, Kuvayı Milliye halinde önemli bir konumda olan Ethem ve müfrezelerinin de böylece etkinliklerini artırdıkları ve herkes üzerinde bir üstünlük tesis etmeye çalıştıkları tespit edilmiştir.

Gediz Taarruzu hakkında Nutuk'ta; taarruzun Türk Erkan-1 Harbiye-i Umumiyesi'nin karşı çıkmasına rağmen, Garp Cephesi kumandanının inisiyatifiyle yapıldığı belirtilmektedir. Ali Fuat Paşa'ya göre ise; askeri bakımdan Gediz baskını zorunludur. Erkan-1 Harbiye-i Umumiye Vekâleti, bilhassa cephanenin azlığından dolayı önce bu harekâta razı olmak istememişse de, sonradan cephanenin İtalya'dan temin olunduğu haberi alınınca muvafakat etmiştir. İsmet Paşa da, yapmış olduğu kuvvet mukayesesi çerçevesinde Erkan-1 Harbiye-i Umumiye Vekili olarak, planlanan taarruza uzun süre karşı çıktığını, durumu yerinde görmek üzere Eskişehir'e gittiğini, orada Ali Fuat Paşa ile görüştükten sonra, birlikte harekâtı ertelediklerini, ancak cephe kumandanı taarruz fikrinde ssrar edince, Mustafa Kemal Paşa'nın araya girdiğini, hepsini dinlediğini ve bu şekilde bir harekâtın yapılmasını, belirli usuller altında onayladığını "Pekâlâ yapınız" 
dediğini belirtmektedir. Başta Mustafa Kemal Paşa olmak üzere, harekâtı onaylama durumunda olan İsmet Paşa ve harekâtı icra eden Ali Fuat Paşa'nın bu konuyu farklı şekillerde yansıttıkları tespit edilmiştir. Neticede taarruz Ali Fuat Paşa'ya göre başarıl1, Mustafa Kemal ve İsmet Paşa'ya göre de başarısızdır. Ancak o dönem için bu taarruz sonucundan en karlı çıkan Ethem ve destekçileri olmuş, düzenli birliklerin aleyhindeki propaganda çalışmaları artmış, kamuoyunda düzenli birliklerden fayda gelmeyeceği algisı yaratılmıştır.

Garp Cephesi Kumandanlığına İsmet Paşa'nın, Cenup Cephesi Kumandanlığına da Refet Paşa'nın getirilmesi üzerine; Ethem'in Eskişehir, Kütahya ve Ankara'da, Tevfik Bey'in cephede Kuvayı Seyyare komutan vekili olarak ve Reşit Bey'in mecliste kendilerini destekleyenlerle birlikte bu duruma tepkilerini artırdıkları görülmektedir. Ethem hatıralarında bu tepkileri inkâr etmemekle beraber, cephede alınan tedbirlerin önemli bir bölümünü de kendisinin teklif ettiğini belirtmektedir. Ancak bu açıklamaların inandırıcılıktan uzak olduğu, somut belgelere dayandırılmadığı, Nutuk'un yazılmasından sonra Nutuk'ta belirtilen hususlara karşı yazılı bir savunma niteliği taşıdığını değerlendirmek mümkündür.

Cephede düzenli orduya geçişle ilgili yapılan düzenlemelere karşı Ethem ve destekçilerinin göstermiş oldukları tepkileri ve buna karşı geliştirilen karşı tedbirleri şu şekilde toparlamak mümkündür:

1. 9 Kasım 1920'de Vekiller Heyeti tarafindan alınan karar gereği, Garp Cephesi Kumandanlığı ikiye ayrılacak, milli kuvvetler ordu kuruluş ve kadroları içine alınacaktır. Ethem ve taraftarları bu duruma şiddetle karşı çıkmışlar, milli hükümete karşı cephe almışlardır. Özellikle Refet Bey'in Cenup Cephesi Kumandanlığına gelmesini istememişler, onun yerine eski Ertuğrul Grup Kumandanı Kazım Bey'in getirilmesini istemişlerdir. Hatta bütün cephenin İsmet Bey kontrolünde olmasını, Ethem bizzat Mustafa Kemal Paşa'ya teklif etmiştir. Buna karşı Garp Cephesi Kumandanı, bölgesinde kesin disiplin ve hükümet otoritesini sağlayıcı tedbirleri geliş̧irmiş̧ir.

2. Düzenli ordu kurulması ve başkomutanlık yetkisinin B.M.M.'ne verilmesine karşı başta Ethem'in kardeşi Saruhan Mebusu Reşit Bey olmak üzere, meclisteki muhalefet ve ağırlıklı olarak Yeşil Ordu Cemiyetine mensup mebuslar karşı çıkmışlar ve "Ordu teşkili bütün dünyada iflas etmiştir. Vatanı kurtaracak olan Milli kuvvetlerdir" temalı propagandayı yoğun bir şekilde sürdürmeye çalışmışlardır. Yeşil Ordu Talimatnamesi Md.2 "...her muharebe ve askerliği nefretle karşılar ve bunlarla mücadele 
eder." ve talimatnamenin 23-30 arasındaki maddeleri tamamen düzenli orduyu reddetmekte ve milis teşkilatlarının kuruluşlarıyla ilgili esasları vermektedir. $^{98}$ Belirtilen esaslar çerçevesinde kendiliklerinden asker toplamaya devam etmişler hatta Cephe Kumandanlığının bilgisi dışında müfrezeler oluşturmuşlardır. $\mathrm{Bu}$ durum da T.B.M.M tarafindan yasaklanmıştır.

Mustafa Kemal Paşa'nın, 8 Ocak 1921 tarihinde, B.M.M.'de; Ethem ve kardeşlerinin durumunu özetlemesi esnasında; birçok delil ve vesikalardan elde etmiş olduğu istihbarata dayalı olarak genel kanaatini açılarken; “...Evvela; Kütahya ve havalisinde kendi tabirlerince bir hükümet, fakat bizim hakikati ifade etmek üzere kullanacağımı tedbirlerle bir derebeylik teşkiline yeltendiler. Bir taraftan bu derebeyliğini Afyonkarahisar'ına, Isparta'ya ve belki Konya'ya, Eskişehir'e kadar teşmile teşebbüs etmekle beraber, memleketin aksam-l sairesinde dahi kuvvetler teşkili ile daha ziyade yaylma ve şekillenme ve binnetice T.B.M.M. 'ni iskat ederek yerine heyet-i umumiyeye hâkim bir hükümet vücuda getirmek istemişlerdir ${ }^{, 99}$ demektedir.

Belirtmiş olduğumuz hususlar dikkate alındığında, Ethem ve destekçilerinin veya onu kullananların asıl amaçlarının ne olduğunu tespit edebilmek mümkündür. Kendilerine özgü siyasi bir yap1 ve bu yapıyı destekleme yeteneğine sahip askeri güçle mevcut hükümetin iş yapamaz hale getirilmesi ve nihayetinde ortadan kaldırılması amaçlanmaktadır. Böyle bir topluluğun, teşkilatın veya grubun düzenli ordu içinde yer almak istememesinin, kontrol altına alınmaktan sakınmasının çok doğal olduğu değerlendirilmektedir.

3. Ethem'in yokluğu esnasında yerine vekâlet eden Tevfik Bey'in yapmış olduğu uygulamalar ve nihayetinde Garp Cephesi Kumandanlığını açık olarak tanımaması; hem Nutuk'ta hem de Ethem'in hatıralarında yer almaktadır. Söz konusu uygulamalar, İsmet Paşa'nın ve Kazım Paşa'nın eserlerinde de teyit edilmektedir. Ethem hatıralarında bu uygulamaların İsmet ve Refet Beylerin lüzumsuz davranışlarından kaynaklandığını, buna dayanarak Mustafa Kemal Paşa'nın da boşuna kuruntuya kapıldığını beyan etmektedir. Oysa yapmış olduğumuz incelemede başta Mustafa Kemal Paşa olmak üzere diğer kumandanların son ana kadar, Ethem birliklerinden yararlanmayı göz ardı etmedikleri ve bunları bir şekilde kontrol altında tutabilme tedbirlerine başvurduklarını görmekteyiz. Bu konuda son ana kadar sabrını zorlamış olan Mustafa Kemal Paşa'nın "Yüzbaşı Tevfik'e bu hareketinin düşman karşısında ayaklanma olduğunu; emir ve komutaya kayıtsız şartsız uyarak eski durumunu devam ettirmek suretiyle görevini

${ }^{98}$ Y1lmaz, a.g.e., s. $161-170$

${ }^{99}$ Atatürk'ün Söylev ve Demeçleri, Cilt I, T.T.K. Basımevi, Ankara, 1997, s. 139. 
yapmasinı bildirmek. Itaat etmezse onu komuta etmekten alıkoymak. Bu halde de Yüzbaşı Tevfik'in kuvvetlerini beraber alacağı ihtimaline karşı gerekli tedbirleri almak. Kendisine mümkün olursa Ethem vasitastyla uygun bir bildiride bulunmak, sonra yeni şımarıklıklarının önüne geçecek şekilde onu itaat altına almak ${ }^{, 100}$ şeklindeki düşünceleri, belirtmiş olduğumuz değerlendirmenin en müspet kanıtıdır.

4. Nutuk'ta belirtildiği üzere Ethem ve kardeşlerinin yola getirilmesi için öncelikle nasihat edilmesi yolu seçilmiştir. Bu maksatla Ethem'in yanına gönderilen Kazım Bey'in Ethem ile yapmış olduğu görüşme sonrası Mustafa Kemal Paşa'ya ilettiği konular, kendi hatıralarında belirtmiş olduklarına benzerdir. Ancak Ethem'in hatıralarında aktardığı hususlar, Kazım Bey'in aktardıklarının tamamen dışındadır. Bilindiği üzere Kazım Bey, Ethem ile görüşmeye 5 Aralık 1920 tarihinde gitmiştir. Kendisi aynı zamanda Karesi Mebusu olduğu için Ekim-Kasım 1920’den beri Büyük Millet Meclisinde görev yapmaktadır. Kendisinin daha önce komuta ettiği Ertuğrul Grubuyla artık bir ilişkisi kalmamıştır. Dolayısıyla herhangi bir birliğe sahip değildir. Oysa Ethem, Kazım Bey'in; eğer Kuvve-i Seyyareye fiili bir saldırı olursa, kendisinin de emrindeki iki piyade firkasıyla buna karşı koyacağını söylediğini beyan etmektedir ki, tamamen asılsız olduğunu değerlendirmek mümkündür.

Ancak bu husus, incelememiz için bazı somut veriler elde etmemize katkıda bulunmuş, Ethem'in hatıralarının doğru bir şekilde kaleme alınışı hakkındaki şüphelerin artmasına neden olmuştur. Dolayısıyla Ethem'in hatıralarının güvenirliliği tam olarak sağlanamamaktadır.

Hatıraların tamamen Ethem tarafından kaleme alındığını söylemek çok güçtür. Bu konuda özel bir inceleme yapan ve hatıraların aslını gördüğünü iddia eden Şevket Süreyya Aydemir; hatıralar hakkında "...Eski harflerle yazllmuş ve aslindan kopya edilmiş üç defter halindeydi. Daha ilk bakışta görülüyordu ki, bunlar aynı insanın elinden çıkmamıştır. Defterlerin birinde sade, gelişigüzel ifade ve üslup, diğer bir defterde oldukça ăgdalı bir Osmanlica halini altyordu. Hatıralar, bizzat Çerkes Ethem tarafindan yazllmayıp, onun ağzından ya kardeşleri, ya da adamları tarafindan kaleme alınmış olabilir. Hatıralarda göze çarpan bir cihet de, tarih eksiklikleri ve önemli tarih çelişmeleridir...,"101 demektedir.

"Çerkes Ethem Hadisesinin Nutuk Temelli" incelenmesinden çıkarılan sonuç şudur ki; Ethem, Milli Mücadele’nin başlangıç safhasında

\footnotetext{
${ }^{100}$ Türk İstiklal Harbi, II.Cilt, Batı Cephesi, 3ncü Kısım, Gnkur. Basımevi, Ankara, 1966, s. 78.

${ }^{101}$ Şevket Süreyya Aydemir, Tek Adam Mustafa Kemal, Cilt II, Remzi Kitabevi, İstanbul, 2009, s. 292.
} 
gerek cephede Yunan birliklerine karşı, gerekse yurt içinde meydana gelen ayaklanmalarda etkin bir şekilde faaliyet göstermiştir. Ancak, Ankara muhitine geldiğinde, meclis içinde oluşan Mustafa Kemal veya ulusal hareket karşıtı muhaliflerin ve muhalif mebusların etkisinde kalarak, daha önce kendi kafasında yer eden Bolşeviklik düşüncelerini pekiştirmiştir. Elinde mevcut kuvvetlerin, kendilerinin izlediği siyasete önemli bir katk1 sağlayacağını uman ulusal hareket karşıtı muhalif politikacıların, kendisini kandırmalarına engel olamamıştır. Bu düşünceler çerçevesinde kendisine bir aidiyet ve hâkimiyet olgusu sağlayacak Yeşil Ordu Cemiyeti mensubiyetini benimsemiştir. Gençlik yıllarında Teşkilat-1 Mahsusa'dan edindiği gayri nizami harp tecrübelerini, ülkenin içinde bulunduğu kargaşa ortamından yararlanarak uygulama alanına koymaya çalışmış, ancak bunda da başarılı olamamıştır.

Mustafa Kemal Paşa ve diğer ulusal liderler ise; günün koşulları çerçevesinde elde mevcut yegâne kuvvet olan Ethem Kuvayı Seyyaresini gerektiği zaman ve yerde, gereken şekilde kullanabilmek için başlangıçta her türlü gayreti göstermiştir. Ancak, yurdun işgalden kurtarılması amacıyla, düzenli Yunan kuvvetlerine karşı mutlaka düzenli bir ordunun kurulması için uygun koşullar oluşmaya başlamış ve çalışmalar bu yönde ağırlık kazanmıştır. Kuvayı Milliye birliklerinin de düzenli ordu bünyesine dâhil edilmesi esnasında, Ethem ve kardeşlerinin göstermiş olduğu tepkiler bulundukları cephenin önemi göz önüne alınarak iyi niyetle ve nasihatle giderilmeye çalışılmıştır. Nihayet durumun adeta bir isyan niteliğine dönüşmesi üzerine, gereken tedbirler geliştirilmiş ve Ethem kuvvetleri önlerindeki düşmanla birlikte sürülerek, Milli Mücadele tarihindeki çok talihsiz bir konuma mahkûm edilmiştir.

\section{KAYNAKLAR}

Atatürk, Gazi Mustafa Kemal; Nutuk, Ankara, 1927.

Atatürk, Gazi Mustafa Kemal; Nutuk, Cilt II, Türk Tarih Kurumu Yayınları, Ankara, 2010.

Atatürk'ün Söylev ve Demeçleri, Cilt I, T.T.K. Basımevi, Ankara, 1997.

Aydemir, Şevket Süreyya; Tek Adam Mustafa Kemal, Cilt II, Remzi Kitabevi, İstanbul, 2009.

Cebesoy, Ali Fuat; Milli Mücadele Hatıraları, Temel Yayınları, İstanbul, 2010.

Çerkes Ethem; Çerkes Ethem'in Hatıraları, Dünya Yayınları, İstanbul, 1962.

İnönü, İsmet; Hatıralar, Bilgi Yayınları, C.I, Ankara, 1992. 
Kutay, Cemal; Çerkes Ethem Tamamlanmış Dosya, Özgür Yayınları, İstanbul, 2004.

Özalp, Kazım Milli Mücadele 1919-1922, Türk Tarih Kurumu Yayınları, Ankara, 1998.

Tevetoğlu, Fethi; Türkiye'de Sosyalist ve Komünist Faaliyetler, Ayyıldız Matbaas1, Ankara, 1967.

Topuz, Hıfzi; II.Mahmut'tan Holdinglere Türk Basın Tarihi, Remzi Kitabevi, İstanbul, 2003.

Türk İstiklal Harbi, II. Cilt, Batı Cephesi, 2. Kısım, Gnkur. Basımevi, Ankara, 1966.

Türk İstiklal Harbi, VI. Cilt, İç Ayaklanmalar 1919-1921, Gnkur. Basımevi, Ankara, 1964

Yılmaz, Mustafa; Milli Mücadelede Yeşil Ordu, Kültür ve Turizm Bakanlı̆̆ Yayınları, No:783, Ankara, 1987.

Yakın Tarihimiz Dergisi, Cilt II.

Yunus Nadi; Kurtuluş Savaşı Anıları, Çağdaş Yayınları, İstanbul, 1978. 
EK-1

\title{
ÇERKES ETHEM'IN DAHILIYYE VEKİLI REFET BEY'E ÇEKTIIĞI TELGRAF
}

\author{
Ankara'da Dâhiliye Vekili Refet Bey'e
}

Dün, Alacalı Dede Galip Bey Zade Gazi Hüseyin Beyden cevaben aldiğım telgrafta; Yozgat ve havalisi ihtilali alakadaranindan, cephelere isstirak etmek suretiyle ve hükümetin karar ve tasvibi ile affedilenlerden bize iltihak eden üç yüz kişilik efrattan beri kalanların toplanmasına memur edilen Hüseyin Gazi'nin sevk ettiği otuz kırk kişinin Ankara'dan iade ve memuriyetini ispat eden Hüseyin Gazi Beye vermiş olduğum vesikanın sizin tarafinızdan alınarak; "Bu gibi mezuniyetler ve muameleler hükümete ve bana aittir" gibi tahkiramiz muamelenizden bahsedilmektedir.

Pek nabemevsim bu muamelenin tarafinızdan yapıldı̆̆ına ihtimal vermemekle beraber, herhalde şayanı takip ve tashih görmekteyim. Vazife-i vataniyemden aylrmak suretiyle o havaliye berayı tedip gönderilmekliğim de hükümetin emriyle ve arzum hilafinaydı. Zatıâli ve emsal müfzelerin havaliyi mezkûrda vazife-i tedibiyenin icrasinda kemali emniyetle, şoselerde gezmek ve seyahat etmek gibi harekâta geçmekte âdemi muvaffakiyetini unutmamak lazım gelir. Zaman ve istikbal daha çok hakiki vatanperverleri meydana ihraç ve maatteessüf sahteleri de itizale icbar etmek tehlikesindedir! Umuru vekâletin de ne suretle uhdenize verildiğinin pekâla farkına varanlardan olduğumu arz ile bu derece nezaketsizce bendenizi mecbur eden kllükalin tashih ve mahalli mezkûr emir vererek Hüseyin Gazinin ve mahiyeti efradının süratle iltihaklarının temin ve izamı ricastyla cevabınıza muntazırım efendim.

Ethem $^{102}$

${ }^{102}$ Yunus Nadi, Kurtuluş Savaşı Anıları, Çağdaş Yayınları, İstanbul, 1978, s. 388. 
EK-2

\section{ÇERKES ETHEM'DEN DEMİRCI MEHMET EFE'YE}

Çerkes Ethem'in İsmet Paşa ile arası açılıp da isyana karar verdiği sırada Demirci Mehmet Efe'ye yazdığı 12 Aralık 1920 tarihli gizli şifre, yakalanan Vacit Bey'in üstünde bulunarak şu şekilde açılmıştır:

“Demirci Mehmet Efe'ye

Muhterem Mücahit Kardeşim Demirci Mehmet Efe'ye

Bizim çalışmalarımızın ve fedakârllğımızın verimli olması, hariç ve dâhile karşı ihtilalin ve memleket müdafaasının lazım gelen intizamda cereyan etmesi için teşekkül ettirilen Ankara Hükümeti, birkaç muhterisin aleti olmaktan kurtulamamakta ve günden güne keyfi ve şahsi ihtiraslartn zebunu olmaktan ileri götürülememektedir. Memleketin bu gidişle kurtulması artık imkân haricindedir. Dış vaziyet, Anadolu Hükümetine elverişli bulunmakla beraber, istifade şöyle dursun, mefsedetle (bozgunculuk) kalınmayarak, münasebetsiz hareketlerine mani teşkil edeceklerini tahmin ettikleri şahsiyeti sizce de malum Sarı Efe Edip ile daha bazılarını da her ne şekilde olursa olsun imhaya karar vermişlerdir. Daha evvel senin imha edilmenin güya memleket hesabına lüzumunu bana ihsas ettirmek ve .......(okunamamıştır) bu düşünceden müteessir olduğu memleketin ve müşterek gayemizin istihsali uğrunda her gün fedakârlıklarla hizmet eden ve edeceklerin neden imhaya şayan görüldüklerini sordum.....(iki kelime okunamamıştır). Biz kendimizden biliyoruz. Onlar ne vakit olsa başımıza beladır, demek kadar gayri makul cevablyla beni hayrette birakı, meseleyi kapadılar. Íptidadan beri çektiğimiz emeklerimizin boşa gitmemesi için, şimdi birbirimize sarılmalıyız. Cevabınızı bekliyorum. Şifremi alır almaz Denizli'ye yaklaşmaya ve benimle sıkı temasa gayret etmeye çalışmanızı ayrica rica ediyorum."

KUVA-YI SEYYARE VE KÜTAHYA HAVALISII KUMANDANI

ETHEM $^{103}$

${ }^{103}$ Yakın Tarihimiz, Cilt II, s. 364. 
EK-3

\section{BÜYÜK MILLET MECLISİ VE GARP ORDUSU KUMANDANLIĞINA ÇEKİLEN TELGRAF}

Çerkes Ethem, Mustafa Kemal Paşa ve arkadaşlarının, her türlü uzlaşma teşebbüslerine rağmen, bilhassa kardeşi Tevfik'in teşvikiyle, kendini akıbetlerin en feciine sürüklediği sırada, Büyük Millet Meclisi ile Erkan-1 Harbiye-i Umumiye Riyasetine ve Garp Ordusu Kumandanlığına hitaben şu şifreli telgrafı göndermişti:

"Bu israflar ve ihtiraslar ile dolu şartlar altında milletin ve memleketin artık harbe tahammülü kalmamıştır. İstanbul'dan gelen ve tevkif edildikleri sabit olan sulh tavassut heyetinin, Ahmet İzet Paşa Heyeti, muvafik ve müsait şartlar altında geldikleri de halk arasında şayi olduğuna göre, bu heyetin serbest birakılarak, sulh müzakerelerine süratle başlanmasını bütün asker ve efrat ve milletin tercümanı olarak ihbar-l keyfiyet eylerim. Ankara'da toplanan meclisin ne şekilde içtima ettiğini tabii hepimiz biliyoruz. Illk toplantıları da bu fakir milletin sırtından kendilerine yılda üç bin lira tahsisat yapmaları olmuştur ki, içlerinde yılda yüz lirayı gören çok azdir. Şimdi bol bol dalkavuklarla me'lufturlar. Bilecik'e gelen Heyet-i Aliye 'nin hemen İstanbul'a iadesi ehemmiyetle maruzdur."

KÜTAHYA HAVALİSİ VE KUVA-YI SEYYARE KUMANDANI

ETHEM $^{104}$

${ }^{104}$ Yakın Tarihimiz, Cilt II, s. 365. 
EK-4

\section{UÇAKTAN ATILAN BEYANNAMELER}

9 Ocak 1921 günü akşamı saat dörtte, yani Yunanlıların İnönü mevzilerimize ilk taarruza geçtikleri gün, Uşak cihetinden gelen bir Yunan uçağının Karahisar üzerinde 15 dakika kadar uçup, şehre ve yakın köylerine attığı, Türkçe basılmış ve Ethem imzalı beyannamelerde aynen şu satırlar yer almaktadır:

"Masum Millet ve Asker Kardeşlerim,

Ankara Hükümet rezilesine, 29 Kanun-u Evvel 1336 tarihinde keşide ettiğim memleket ihtiyaçlarına müteallik telgrafin matbuat ile ilan edilmesini isteyiniz. Ahiretteki mesuliyetinizden korkunuz. Maziden intibah alarak her türlü felaketi ve vatanı kurtarmağ isteyenlere karşı hakkınızı müdafaa ediniz. Şahsi ihtiraslara alet olmayınız. Ey zabit arkadaşlar, emir kulu olmaktan sarfi nazar ediniz. Allah'in kulu değilseniz, aksi halde geliyorum ha!... Son pişmanlık fayda vermez!"

UMUM KUVA-YI MILLIYE KUMANDANI

ETHEM $^{105}$

${ }^{105}$ A.g.e., s. 365 . 